\title{
Physicochemical and Bacteriological Quality of Ground Water in the Basin of Gounti Yena Valley in Niamey City (Niger Republic)
}

\section{Halidou Alassane Hado1, Mahaman Moustapha Adamou', Guillaume Favreau', Karmadine Hima ${ }^{3}$, Ibrahim Dan Dano4, Abdourahmane Toure Amadou', Nafissa Saidou ${ }^{5}$}

${ }^{1}$ Faculty of Agronomy, Abdou Moumouni University of Niamey, Niamey, Niger

${ }^{2}$ IGE, Grenoble INP, CNRS, IRD, Grenoble Alpes University, Grenoble, France

${ }^{3}$ Faculty of Science and Technology, Abdou Moumouni University of Niamey, Niamey, Niger

${ }^{4}$ Medical and Health Research Center, Niamey, Niger

${ }^{5}$ Quali Control Lab, Niamey, Niger

Email: moustapha_a@yahoo.com

How to cite this paper: Hado, H.A., Adamou, M.M., Favreau, G., Hima, K., Dano, I.D., Amadou, A.T. and Saidou, N. (2022) Physicochemical and Bacteriological Quality of Ground Water in the Basin of Gounti Yena Valley in Niamey City (Niger Republic). Journal of Water Resource and Protection, 14, 186-220.

https://doi.org/10.4236/jwarp.2022.142010

Received: January 19, 2022

Accepted: February 25, 2022

Published: February 28, 2022

Copyright (C) 2022 by author(s) and Scientific Research Publishing Inc. This work is licensed under the Creative Commons Attribution International License (CC BY 4.0).

http://creativecommons.org/licenses/by/4.0/ (c) (i) Open Access

\begin{abstract}
The Gounti Yéna valley, the subject of this study, is a tributary of the Niger River, it is the main watercourse that divides the left bank of the city of Niamey into two unequal parts. The surface area of its watershed is estimated at about $62 \mathrm{Km}^{2}$. The objective of the present study is on the one hand to evaluate the current state of the physico-chemical and bacteriological quality of the water of Gounti Yéna basin, and on the other hand to define the risks of water pollution and its origin in the face of the phenomenon of rising water table of this basin. In order to carry out this work, we proceeded to a study of the evolution of the physicochemical and bacteriological parameters of the water of the basin of Gounti Yéna during the period going from November 2020 to October 2021, at the level of four points of sampling chosen from the upstream to the downstream of the basin. The results obtained showed that the physico-chemical quality of the water in Gounti Yéna basin is influenced by the lithology of the watershed, climatic factors (rainfall and temperature) and anthropic actions. This study also highlighted the presence of fecal contamination in the water of the Gounti Yéna basin, with a greater degree of emphasis during the rainy season. This contamination remains a concern and may constitute a health risk.
\end{abstract}




\section{Keywords}

Pollution, Physicochemistry, Bacteriology, Water Table, Flooding, Niamey

\section{Introduction}

Today, the world is facing many challenges, including an ever-increasing population and often anarchic urbanization [1]. It is believed that population growth accompanied by rapid urbanization is causing numerous disturbances to the natural environment.

Not a single region of the world is immune to meteorological mood swings, only, depending on certain parameters such as their geographical position, their geological and geomorphological nature some are more exposed than others. In the Sahel, one of the parameters of climate change is an exacerbation of climatic hazards, including floods. For several decades, the populations of West African cities have been confronted with flooding problems. The causes of flooding in the various African cities are almost everywhere the same. They are always caused by climate change, accentuated by the effects of demography, the anarchic expansion of cities, the lack of drainage systems, deforestation, etc. In Niger, floods are now at the heart of the disaster risks faced by the country. They are the second most common natural disaster after droughts. Floods are not a new phenomenon in Niger because, since the beginning of the 1990s, there has been an increase in floods throughout the country. These can take many forms, including rising water tables and runoff due to climate change and anthropogenic effects. In the city of Niamey, there are three types of flooding [2].

Pluvial floods due to the recording of heavy rains in the city of Niamey. These floods affect almost all the districts of the capital due to the inadequacy or lack of a sewerage system.

River flooding: this is observed in the districts along the river, below $180 \mathrm{~m}$ in altitude. They occur most often during periods of flooding, which are of two types (local flooding and Guinean flooding).

Floods due to the rise of the water table or floods. In the city of Niamey, there are sectors that are flooded 12 months out of 12, particularly in the SONUCI, Dar-Es-Salam, Bobiel and Foulan Koira districts. These floods are due to the rising water table on the surface.

In Niamey, rainfall is characterized by great variability in space and time, from one year to the next and according to dry or wet periods [2]. In addition to these variabilities, the modification of the vegetation cover disrupts the distribution of water at the surface and in the soil. If the aquifers of CT1 and CT2 seem hydraulically not very active, the surface water table (CT3). On the contrary, it is regularly fed by the rains and the volumes circulating in it are much greater than in the levels below Niamey. For example, on the slopes and lowlands of southwestern Niger, the replacement of the natural savannah by millet crops has had a 
triple action favoring runoff, the concentration of runoff in the lowlands and then the recharge of the water table, which is multiplied by ten [3] [4].

Throughout the Sahel, the droughts of the 1970s and 1980s led to a significant drop in groundwater levels. In recent years, with the return to normalcy, many studies have attempted to highlight the rise in the water table, for example [5] states that the water table in southwestern Niger has been rising continuously for the past decades (4 m rise from 1963 to 2007). Boubakar H., 2010 [6] who noted a rise of $2.2 \mathrm{~m}$ in ten years in the city of Niamey on a well and Alassane Hado H. et al., 2021 [2] having observed a rise of 20 and $40 \mathrm{~m}$ in 60 years in the same city where this water table can outcrop in some places with many impacts. In the city of Niamey, flooding by an accumulation of runoff water or by indirect overflow (water rises through the alluvial water table in the sewerage system) has been observed on the left bank of the river [7].

These floods lead to the collapse of wells or the submergence of access roads to water points, aggravating the sanitary conditions of water extraction and transport, and making the water unsafe to drink. In these areas, individual or collective sanitation (wastewater, rainwater and household waste disposal) is nonexistent or non-functional [8], which exposes this environment, in addition to being urban, to a pollution phenomenon. Indeed, the urban environment represents by definition a concentration of activities and populations, the importance of which conditions the complexity of the various equipment to be implemented. This problem of pollution is known in all the large cities of the world, and has been the subject of many debates. Wells are still very vulnerable to pollution, especially from latrines and septic tanks. Septic tanks play an important role in the transmission of bacteria, as well as the different layers of the soil. $\mathrm{Ni}$ trate pollution has already been highlighted by [9] and [10]. [11] recommends the monitoring of water quality in the city of Niamey. As far as microbiological pollution is concerned, [12] confirms that the water of this city is really impacted.

With this rise in surface water, we observe the stagnation of water that now constitutes permanent pools with the development of the female anopheles causing malaria, without noting the appearance of other water-borne diseases. These floods also cause many environmental, social, economic and health impacts. Developing countries are the most affected by these health problems because, due to lack of resources, water does not undergo purification treatment before being consumed and the quality of this water has deteriorated during its transport. As a result, nearly two million people in poor countries die every year from diarrheal diseases caused by unsafe water, poor hygiene and inadequate sanitation [13]. It is most often difficult to prove that the cause is water. Some [14] believe that the problem affects more the vulnerable and poor populations of the disadvantaged neighborhoods, while the flooded SONUCI neighborhood in Niamey is rather a symbol of an economic success story of the 1980s. 


\section{Material and Methods}

\subsection{Presentation of the Site}

A small village in the 1930s, Niamey became the first urban center in Niger in 1952 , with 11,790 inhabitants; in 1972, its population exceeded 100,000 [15]; this population exploded between 1960 and 2020. As of December 2012, the population of the study area is $1,026,848$. The urban community of Niamey, today with city status forms an enclave in the department of Kollo (Figure 1). Its altitude ranges from $160 \mathrm{~m}$ to $258 \mathrm{~m}$. It is divided administratively into five communal districts and today has nearly 1.5 million inhabitants and covers nearly $300 \mathrm{~km}^{2}$ [16].

The relief of the city is not very marked, on the left bank of the river, upstream from the alluvial plain, a plateau rises to an altitude of about $230 \mathrm{~m}$. The city of Niamey is mainly developed on this plateau covered by thin formations [7]. Annual rainfall has generally varied from 500 to $750 \mathrm{~mm}$ with a very exceptional extreme of more than $800 \mathrm{~mm}$ in 1998; the average annual temperature from 1995 to 2004 is $30^{\circ} \mathrm{C}$. The highest temperatures are recorded in April and May at $35^{\circ} \mathrm{C}$ [17]. However, [6] states that in recent years, rainfall (annual accumulation) rarely exceeds $600 \mathrm{~mm} /$ year.

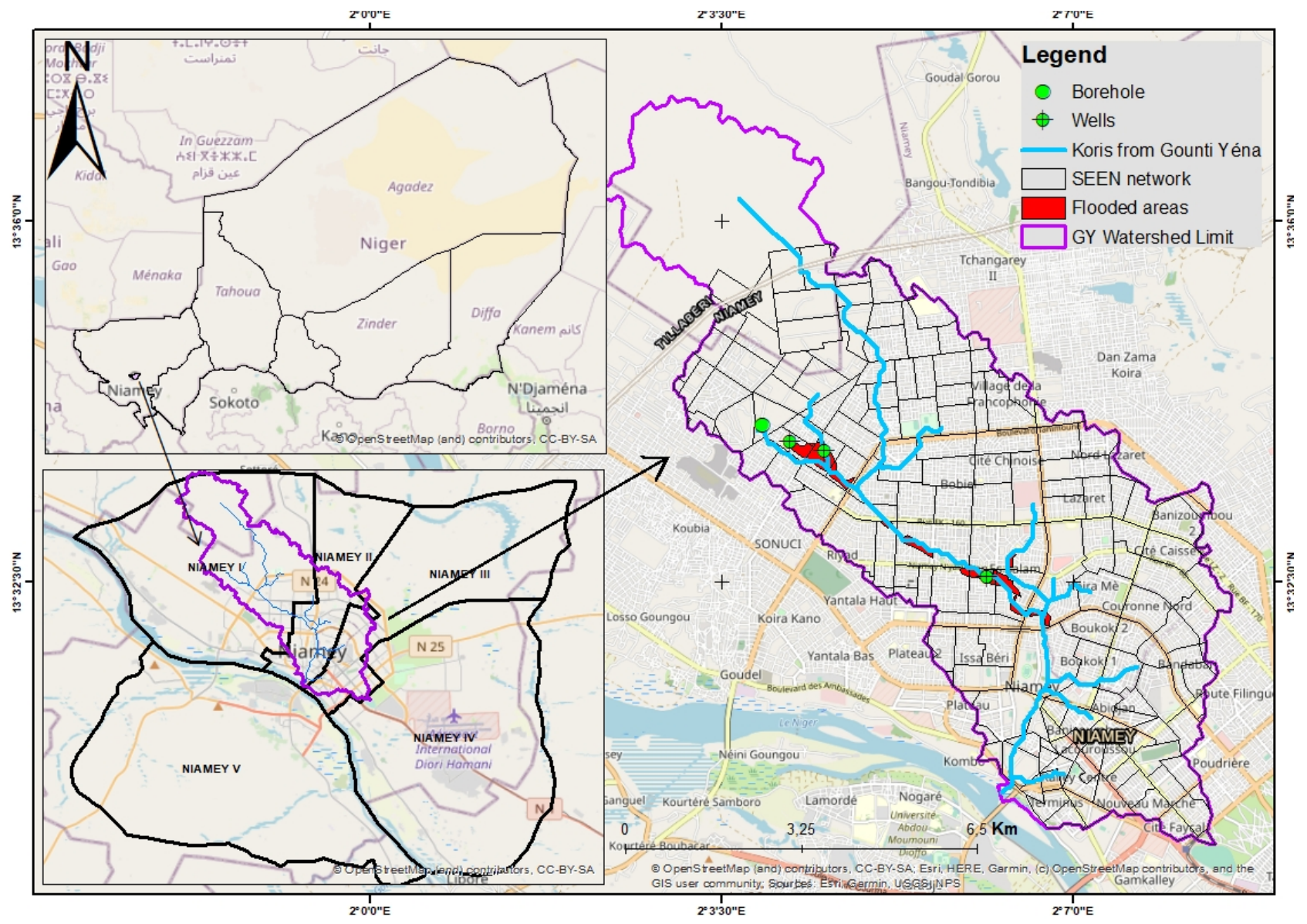

Figure 1. Location of the study area and distribution of sampling points. 
The Gounti Yéna valley, the subject of this study, is a tributary of the Niger River and has become one of the main sites of domestic wastewater in Niamey [18]. The Gounti Yéna is currently an almost permanent feature following the drainage of wastewater and groundwater [16] [19].

Located in communal districts I, II and III (Figure 1), this valley collects wastewater and rainwater from several districts of the city, from Boukoki to the Zongo district before discharging into the Niger River between the Palais des Congrès and the Gawaye Hotel (Figure 1).

Overall, the groundwater in Niamey is polluted and this pollution has increased since $1995[20]$.

\subsection{Domestic Water Supply Sources}

Water supply is provided by surface water (rivers, lakes, ponds, dams), groundwater (wells, boreholes, springs) and rainwater [21]. In the city of Niamey, water supply is provided by the Société des Eaux du Niger (SEEN), which distributes water from the Niger River after seven stages of treatment to subscribers divided into individual, private, social, standpipe, commercial, large-scale consumer, diplomatic representation, state budget administration, state subsidy, state subsidy offices and local authorities. After treatment, this water is sent to the distribution network. The rate of water supply to this population is $82 \%$ in 2014 . The small part not yet served (Figure 1) of Gounti Yéna basin exploits water from wells or boreholes often made without respecting standards for domestic needs. Water needs are not constant over time. In Niamey, they are closely linked to population growth and the extension of the water supply network [22].

\subsection{Surface Water}

Surface water includes streams (rivers) and natural or artificial reservoirs. These surface water have a more or less regular quality depending on the discharges that flow into them or on rainfall runoff [23]. They have the advantage of quantity but the major disadvantage of being highly charged with suspended matter, and even with pathogenic elements; this implies often complex and expensive treatments to make the water drinkable for domestic use. The literature shows that surface water is only consumed directly in rural areas where there is no public water supply or where boreholes are out of order [24]. In the Niamey region, there are no permanent rivers other than the Niger River and the few significant intermittent rivers are on the right bank [25].

\subsection{Groundwater}

Groundwater is the preferred water resource for drinking water, as it is safer from pollutants than surface water [26]. They are the water of the aquifers, layers of permeable ground saturated with water.

The first water table encountered below the ground is the water table located at a depth of fewer than 50 meters and generally separated from the surface by a 
few layers of permeable soil in some places. To collect this water, wells, boreholes and springs are used depending on the depth of the water table and rarely depending on the needs.

\subsection{Geology of the Study Area}

The geology in Gounti Yéna basin is made up of three (3) geological entities: At depth, the Meta-Liptako basement of lower Proterozoic age is composed of plutonic (granites, granulites) and metamorphic (gneisses, quartzites, greenschists) rocks in different states of alteration; This basement is covered by the Terminal Continental of middle Eocene to Pliocene age and consists of alternating sandstones more or less clayey and versicolored clays with intercalations of levels of ferruginous oolites, these are the lands outcropping in the region west of Niamey belong to a vast spread quasi-horizontal sandy-loam reinforced by lateritic or grésifiés levels and crowned by a cuirassed plateau. However, Niamey being located on the extreme southwestern edge of the Iullemmeden basin, it comprises only one layer known as CT3 [27]. Finally, near the Niger River and at the level of the koris are the quaternary alluviums which are composed of coarse, loosely compacted sands.

\subsection{Hydrogeology of the Study Area}

The three geological formations give rise to different aquifers: the basement aquifer captured by the deep boreholes, the Continental Terminal 3 (CT3) aquifers and the alluvial aquifer captured by the shallow wells and sumps. The piezometric levels measured in 2020 and 2021 confirm a groundwater flow that runs mainly from NNW to the South [11] towards the river and a drainage towards the Gounti Yéna that is superimposed on this main flow axis [2]. The hydrogeological functioning of the Continental Terminal water table has been studied and detailed by Leduc et al., 1996 [28].

\subsection{Origin of the Rise of the Water Table in Niamey}

After the two great decades of drought that affected the Sahel, the return to normal is taking place through fairly normal rainfall. However, the annual rainfall total is not the only explanation for the phenomenon. Nor is the increase attributable to a decrease in withdrawals, since, on the contrary, there has been a multiplication of withdrawal points and a doubling of the population in 20 years. The most obvious and logical explanation is that the change in vegetation cover has increased infiltration to the water table, with a decrease in the demand on the water table due to the expansion of the city's drinking water distribution network.

Elsewhere, the modification of the vegetation cover has a double impact on the evolution of water resources. On the one hand, the replacement of natural vegetation by rain-fed crop fields results in less water being drawn from the aquifer. On the other hand, the depletion of vegetation cover clearly increases run- 
off. However, in addition to the climatic and anthropogenic conditions leading to these rises, natural conditions linked to the geology and geomorphology of the area must be taken into account.

\subsection{Setting up a Monitoring Network}

The monitoring network is composed of one borehole and three wells (all private) (Figure 1). The results of the measured parameters will be presented in correlation with the piezometric levels of the wells.

\subsection{Piezometric and Rainfall Data}

Piezometric readings have been conducted on private wells since 2019 at weekly measurement steps during the rainy season and monthly steps in the dry season. This is to assess and better understand the response of the water table to rainfall inputs. Even if a large part of these wells have levels below $3 \mathrm{~m}$. As for the rainfall readings, they are taken from two direct-reading rain gauges set up as part of this work (upstream flooded sector and downstream flooded sector).

\subsection{Frequency of Measurements}

Within the framework of this study, various parameters were determined with regard to water quality: physicochemical and bacteriological parameters (E. Coli).

For the physical parameters, such as conductivity, temperature and $\mathrm{pH}$, they were taken during the two main periods of variation of the water table during the year 2021, namely the "high water" period in September when the water table reached its maximum rise and the "low water" period in May when the lowest level of the water table is recorded. These measurements are made at the scale of the basin with a good distribution on wells (63 in total), which then allowed interpolating these values in order to establish a cartography. Thus, we can easily observe the variations of these parameters according to space and time.

Regarding the physicochemical analyses, major ions and some heavy metals were measured, they are: Calcium, Magnesium, Sodium, Potassium, Bicarbonates, Chloride, Sulfates, Nitrates, Lead, Ammonium, Cadmium, Copper, Nickel, Chromium, Zinc, Phosphorus and Iron. These elements were measured and monitored in the different samples mentioned above at monthly measurement steps for one year during the period from November 2020 to October 2021.

The microbiological characterization was focused on the levels of indicators of fecal contamination described by [29] and [30]. The levels of indicators of fecal contamination were focused on the determination of the rate of E-coli. These levels were determined and their evolution followed in the same samples. This time, during three periods: the rainy season, the cold dry season and the hot dry season.

\subsection{Sampling Campaigns}

Within the framework of this study, campaigns were carried out with the aim of 
taking samples that were subsequently analyzed at the Quali-Control-Lab, at the Faculty of Agronomy of the University of Niamey and at the IRD, represented in Niger. These samples are intended to control the physicochemical and bacteriological quality.

For the physical parameters $\left(\mathrm{T}^{\circ}, \mathrm{C}\right.$ and $\left.\mathrm{pH}\right)$; they were determined in situ as in [31].

The water is taken in two different $500 \mathrm{ml}$ sterilized bottles. The bottle intended for the physicochemical analyses is filled to the brim to avoid the formation of air bubbles. For the determination of bacteriological parameters, the botthe is not completely filled in order to allow the bacteria to grow well. Both vials are stored in a cooler and transported to the laboratory.

A total of 816 measurements were made, 204 measurements per sample at the four selected sampling points.

\subsection{Tools}

For the determination of the physicochemical parameters, the materials used are: the digital titrimetry $\mathrm{HACH}$, the spectrophotometer $\mathrm{HACH} \mathrm{DR} / 3800$ and the flame photometer of mark JENWAY PFP 7.

For microbiology, we needed several tools such as 2 pipettes: $1 \mathrm{ml}$ and $9 \mathrm{ml}, 1$ pipette 8 tips, 4 trays, 4 sterile bottles of $15 \mathrm{ml}$, sterile tips, ringers lactate, 1 marker, gloves, a support for bottles and a trash can.

For piezometry, a 50 meter long light and sound piezometer probe was used.

\subsection{Analytical Techniques for Physicochemical and Bacteriological Parameters}

A small number of chemical contaminants in drinking water are harmful to human health when exposed for a long time. However, they represent a very small proportion of the chemicals from various sources that can enter the water. Physicochemical parameters related to the natural structure of water include temperature, $\mathrm{pH}$, conductivity, major ions: bicarbonate, chloride, sulfate, calcium, magnesium, sodium, potassium and others [32].

In contrast to the microbiological risk, which is short-term, the chemical risk is essentially medium and long-term [33].

\section{Methodological Approach}

\section{$凶$ Physicochemistry}

The different analytical techniques for chemical parameters are as follows:

- Volumetry: The chemical parameters determined are: Calcium, Magnesium (EDTA test), Bicarbonates (sulfuric acid test), Chloride (silver nitrate test).

- Spectrophotometry: The parameters determined by this technique are Nitrites, Nitrates, Iron, Sulfates, Zinc, Phosphorus, Cuivre, Cadmium, Ammonium, Nickel and Chromium.

- Flame photometry: For this technique, the apparatus used is the flame photometer to determine Sodium and Potassium. 


\section{$凶$ Microbiology}

Drinking water must be free of pathogenic microorganisms and must be free of any bacteria indicative of fecal contamination. Bacteria belonging to the coliform group as indicators of fecal contamination define the reference bacteria with Escherichia coli (indicators of recent pollution) as the main representative of this group of bacteria.

For the enumeration of Escherichia coli, the microplate technique with the use of MUGs has been recognized as being more specific, more accurate, more precise and faster than previously used methods. It represents an important evolution compared to the usual techniques for Escherichia coli which, among the indicator microorganisms of fecal contamination, is of particular interest.

The aim here is to carry out a qualitative and quantitative characterization of the microorganisms (Escherichia coli: indicator of fecal contamination) of the different water samples along the Gounti Yéna basin.

The plates have 96 wells with 12 rows of 8 wells. The manipulation consists in making develop the micro-organisms of the water sample in an incubator, after this one underwent progressively, several successive dilutions (4 in our case), put in contact with ringers lactate which will act as nutrient for the micro-organisms then put in the 96 wells of our plate and closed thanks to a plastic in order to prevent the evaporation and any other contamination The incubator should ideally be at a temperature of $44^{\circ} \mathrm{C}$, because Escherichia are thermo-tolerant and this will already allow making a kind of filtration by eliminating the other types of microorganisms not supporting such heat. Incubation can be done at (44.0 \pm $0.5)^{\circ} \mathrm{C}$ for a minimum of 36 hours and up to a maximum of 72 hours, in this study, it is done at $44^{\circ} \mathrm{C}$ and for 48 hours. After incubation, the wells showing blue fluorescence under UV at $366 \mathrm{~nm}$ are considered positive and later the calculation of Most Probable Number (MPN). The MPN represents the statistical estimate of the concentration of the desired microorganisms in the sample analyzed. This estimate follows the Poisson distribution. The lower and upper limits correspond to a $95 \%$ confidence interval. The detection limit is $75 \mathrm{MPN} / 100 \mathrm{ml}$.

\section{Results and Discussion}

\subsection{Water Facies}

To compare the water, we represented the chemical analyses as triangular (Piper) and semi-Logarithmic (Schoeller-Berkaloff) diagrams.

\section{$凶$ Piper diagram}

Piper diagram can be used to demonstrate the hydrochemical facies of analysed water samples. This diagram provides a convenient method to display, classify and compare water types based on the ionic composition of different water samples [34]. Plotting the annual average results of the chemical analyses of the water samples from the Terminal Continental 3 aquifer on the Piper diagram (Figure 2) shows that three quarters of the samples are in the sodium and potassium pole and the remaining quarter are in a mixed enclosure in the cation 


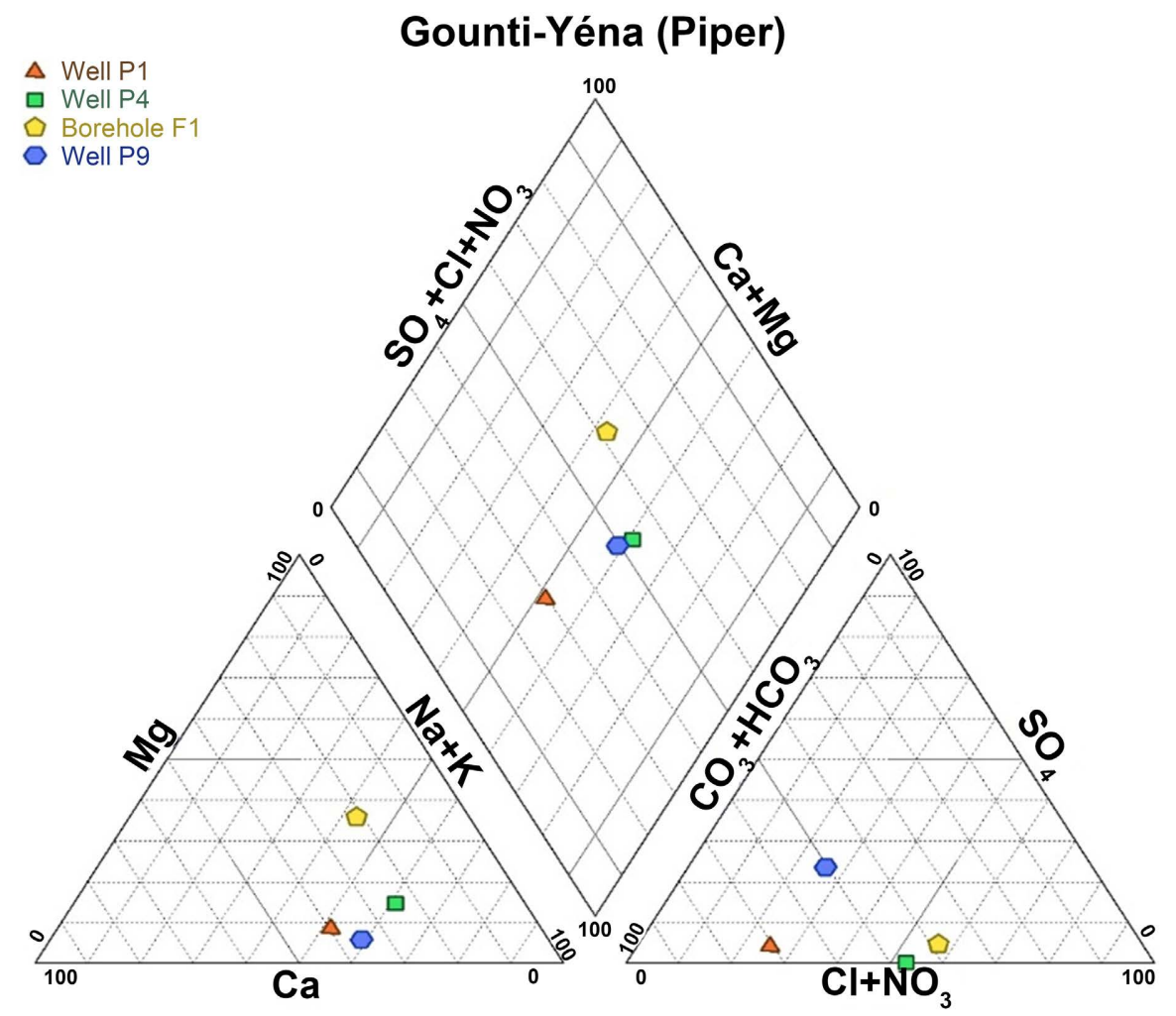

Figure 2. Piper diagram of the water in the study area.

triangle. The bicarbonate and chloride poles share the samples with parity at the anion triangle.

Projection of these samples onto the diamond diagram gives two types of facies (Figure 2); these are the sodium-potassium bicarbonate facies for all the samples from the wells, and borehole F1, which has a chloride and calciummagnesium sulfate facies.

The concentration of anions follows the order of decrease: $\mathrm{HCO}_{3}^{-}, \mathrm{Cl}^{-}$, $\mathrm{SO}_{4}^{2-}, \mathrm{NO}_{3}^{-}$and that of cations decreases following this order: $\mathrm{Na}^{+}, \mathrm{Ca}^{2+}, \mathrm{K}^{+}$, $\mathrm{Mg}^{2+}$.

Nitrates are the main anions when mineralization is high while bicarbonates are more significant when mineralization is low [35], so in the face of relatively low mineralization, bicarbonates dominate over nitrates.

\section{$凶$ Schoeller Berkaloff diagram}

The Schoeller Berkaloff diagram is a semi-logarithmic diagram that allows the results of chemical analyses to be represented graphically. Thus, the annual average of the results of the chemical analyses of the water samples of the study area reported on the Schoeller Berkaloff Diagram (Figure 3) shows peaks obtained at the bicarbonate pole and at the sodium and potassium pole in the Shoeller Berkaloff Digram, this confirms the name of the facies, it is of the sodium bicarbonate and potassium type for the wells. The parallelism of the representative curves of the well samples implies that they are of the same origin (Figure 3). 


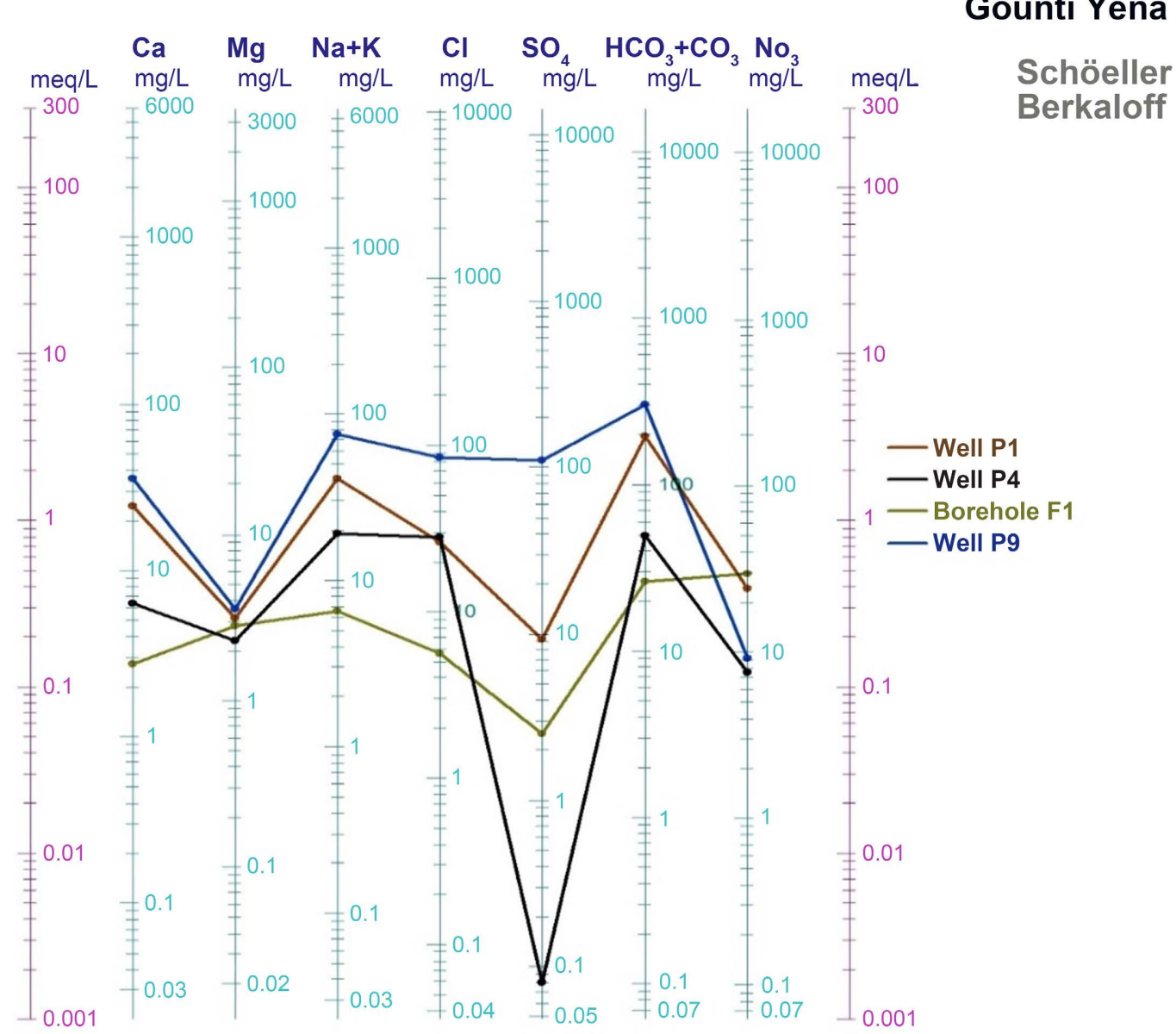

Figure 3. Schoeler Berkaloff diagram of the water in the study area.

\subsection{Physical Parameters}

\subsection{1. $\mathrm{pH}$}

The $\mathrm{pH}$ of water allows highlighting the chemical species present in a sample. It is referred to as acidic $\mathrm{pH}$, neutral $\mathrm{pH}$ or basic $\mathrm{pH}$. The $\mathrm{pH}$ is measured by a potentiometric method by measuring the potential difference between a glass electrode and a reference electrode. There are no health-based guide values for $\mathrm{pH}$. Although $\mathrm{pH}$ does not usually have a direct effect on consumers, it is one of the most important operational parameters of water quality.

All of the measured wells tap into the Ct3 water table. The temporal evolution of $\mathrm{pH}$ for all these wells shows a slight decrease during the rainy season. In particular, with the arrival of new rainfall, the mass of acid precipitation accumulated during the dry season recharges the water table and lowers its $\mathrm{pH}$. These observations are in agreement with the work of [36] and [37].

The water of the CT3 aquifer is acidic with a $\mathrm{pH}$ ranging from 4.9 to 7.0 with a median value of 6.2 [38]. The $\mathrm{pH}$ values in this study indicate that the water is acidic to slightly basic with a $\mathrm{pH}$ ranging from 5 to 8 (Figure 4) during the low water period and from 4 to 8 (Figure 5 ) at the high water period. This difference in value with the work of [37] may be due to the urbanized nature of our 


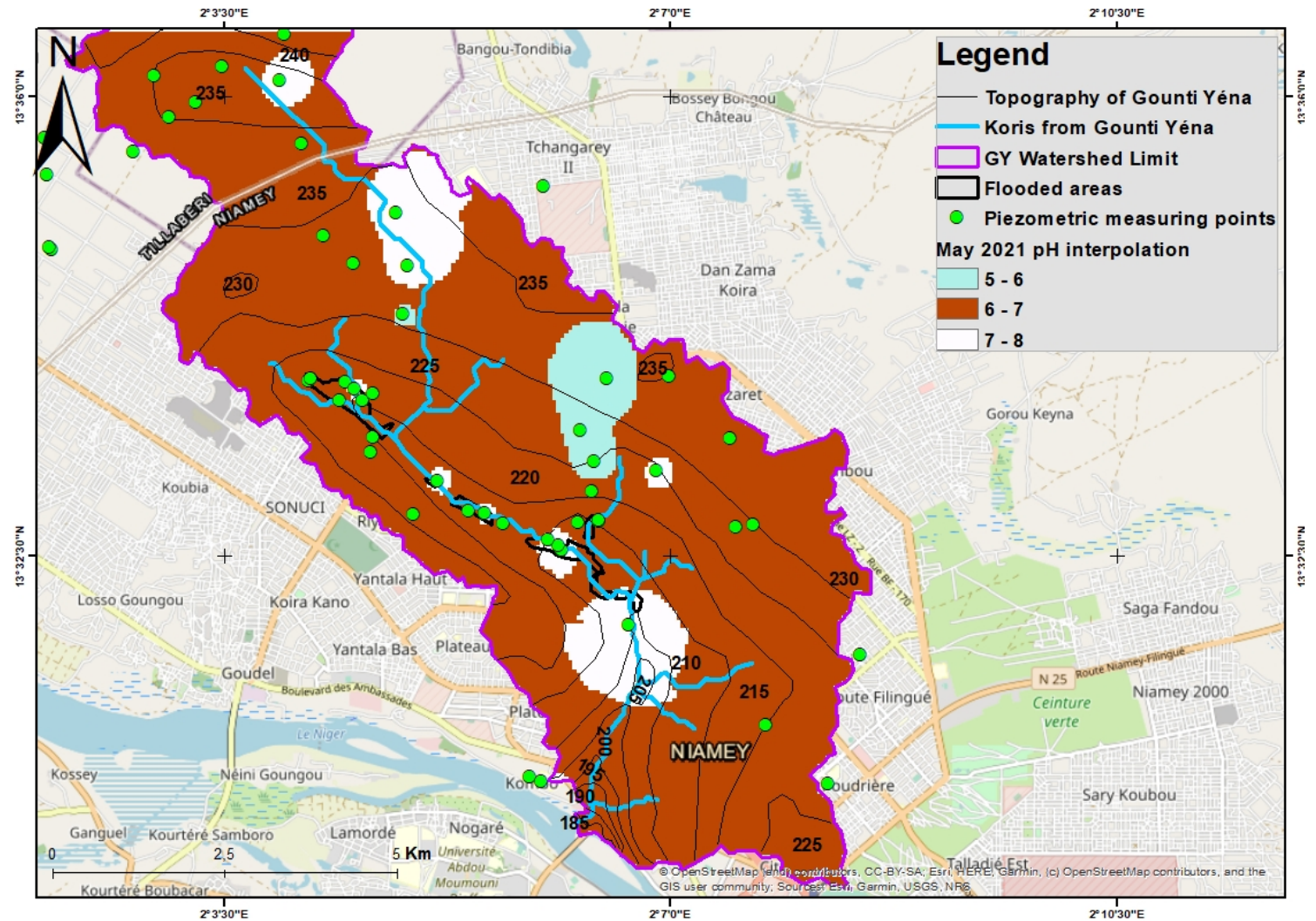

Figure 4. $\mathrm{pH}$ map in low water.

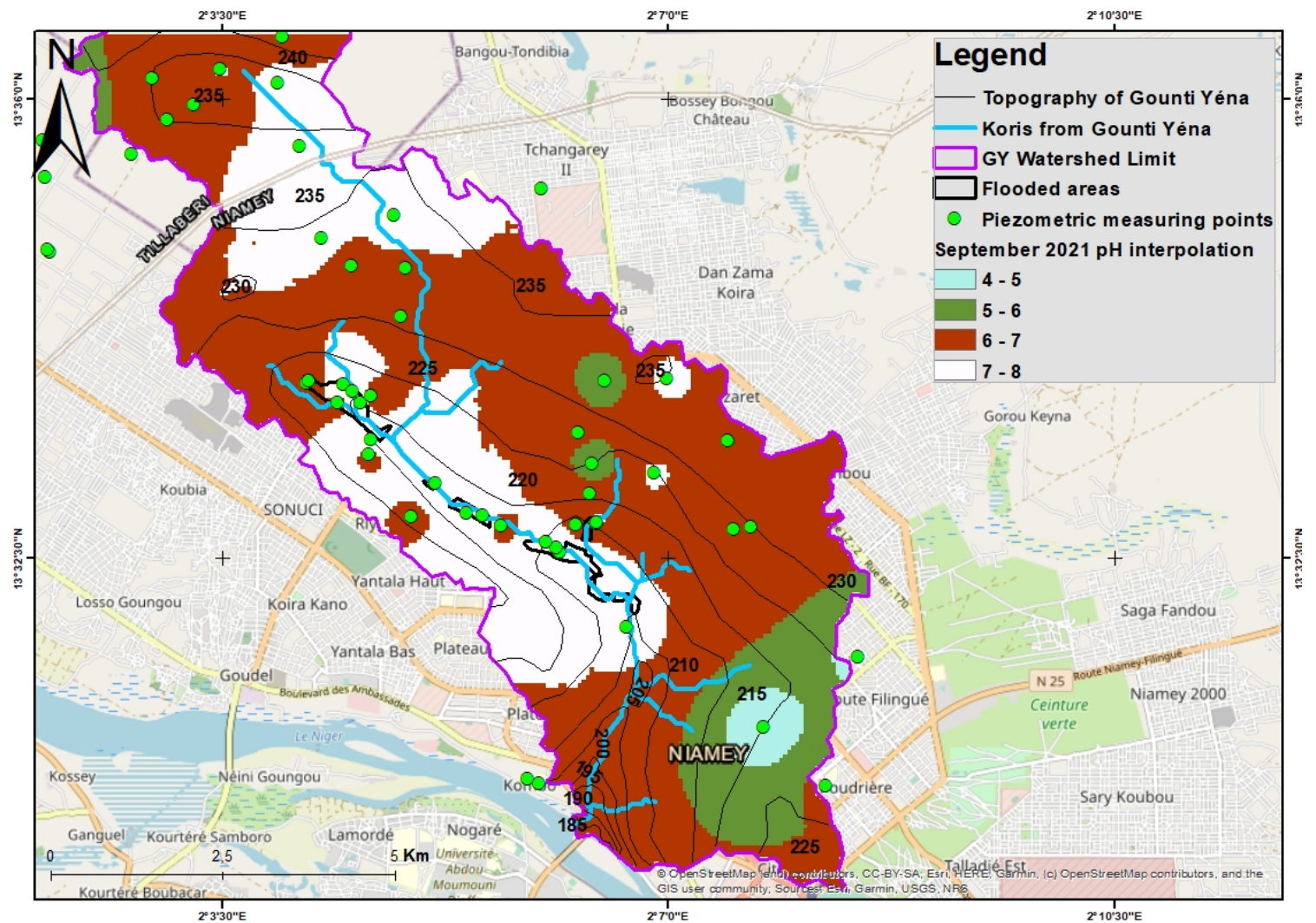

Figure 5. $\mathrm{pH}$ map in high water. 
results. Furthermore, [38] states that the axis of Gounti Yéna appears to be a zone of relatively more basic or neutral $\mathrm{pH}$ and that the left bank was in 1986 a zone of generally neutral $\mathrm{pH}$ and locally weakly acidic or basic. This is reflected in the maps in Figure 4 and Figure 5.

The higher $\mathrm{pH}$ values may be the result of $\mathrm{CO}_{2}$ consumption or degassing that results in a relative increase in $\mathrm{CO}_{3}^{2-}$ ion compared to $\mathrm{HCO}_{3}^{-}$ion.

\subsubsection{Hardness}

Water hardness is due to a variety of dissolved polyvalent metal ions, mainly calcium and magnesium cations. It is usually expressed in milligrams of calcium carbonate per liter. Hardness is the usual measure of the ability of water to react with soap, with hard water requiring considerably more soap to produce foam. The total hardness of water is produced by the calcium and magnesium salts it contains. It mainly affects the condition of pipes and heating appliances, and the washing of clothes. In this study, it is evaluated from the average of the different values of $\mathrm{Ca}$ and $\mathrm{Mg}$ acquired. It is measured by the hydrometric title which is expressed in $\mathrm{mg} / \mathrm{l}$ of $\mathrm{CaCO}_{3}$, in $\mathrm{mg} / \mathrm{l}$ of $\mathrm{Mg}$ or $\mathrm{Ca}$. The hydrometric title can also be expressed in French degree $\left({ }^{\circ} \mathrm{F}\right)$ and is obtained from the following formula:

$$
\left({ }^{\circ} \mathrm{dh}\right)=\mathrm{Ca}^{2+} \frac{\mathrm{CaCO}_{3}}{\mathrm{Ca}}+\mathrm{Mg}^{2+} \frac{\mathrm{CaCO}_{3}}{\mathrm{Mg}}(\mathrm{mg} \text { or } \mathrm{ppm}) \text { or }\left({ }^{\circ} \mathrm{dh}\right)=2.5 \mathrm{Ca}+4.16 \mathrm{Mg}
$$

where $1^{\circ} \mathrm{F}$ is equivalent to $10 \mathrm{mg} \mathrm{CaCO}_{3}$. The classification is then established as follows:

Very soft water: $\left({ }^{\circ} \mathrm{dh}\right)<3^{\circ} \mathrm{F}$; Soft water: $3^{\circ} \mathrm{F}<\left({ }^{\circ} \mathrm{dh}\right)<15^{\circ} \mathrm{F}$; Hard water: $15^{\circ} \mathrm{F}$ $<\left({ }^{\circ} \mathrm{dh}\right)<35^{\circ} \mathrm{F}$ and Very hard water: $\left({ }^{\circ} \mathrm{dh}\right)<35^{\circ} \mathrm{F}$.

After classification, the water in the study area range from very soft to soft (Table 1). Wells P1 and P9 have a soft character while well P4 and borehole F1 have a hardness that is in the "very soft" class.

\subsubsection{Temperature}

Groundwater temperature is related to factors such as its proximity to the ground surface and seasonal variations. The temporal evolution of temperature for all wells indicates that the water temperature follows the air temperature (Figure 6 and Figure 7). These values reflect the annual atmospheric temperature at the Niamey station. They are consistent with results found by [7] stating that temperatures increase significantly in the CT3 aquifer during the hot season (April) by an average of $1^{\circ} \mathrm{C}$ compared to the temperature at the beginning of the campaign (March), temperatures of $26.7^{\circ} \mathrm{C}$ to $33^{\circ} \mathrm{C}$ with an average of $30.6^{\circ} \mathrm{C}$

Table 1. Hardness of Gounti Yena water and its effect on a material.

\begin{tabular}{ccccc}
\hline Water source & Well P1 & Well P4 & Borehole F1 & Well P9 \\
\hline$\left({ }^{\circ} \mathrm{dh}\right)$ in ${ }^{\circ} \mathrm{F}$ & 7.36 & 2.53 & 1.87 & 10.42 \\
Classification & Soft & Very soft & Very soft & Soft
\end{tabular}

Effect on a material No effect Corrosion of material Corrosion of material No effect 


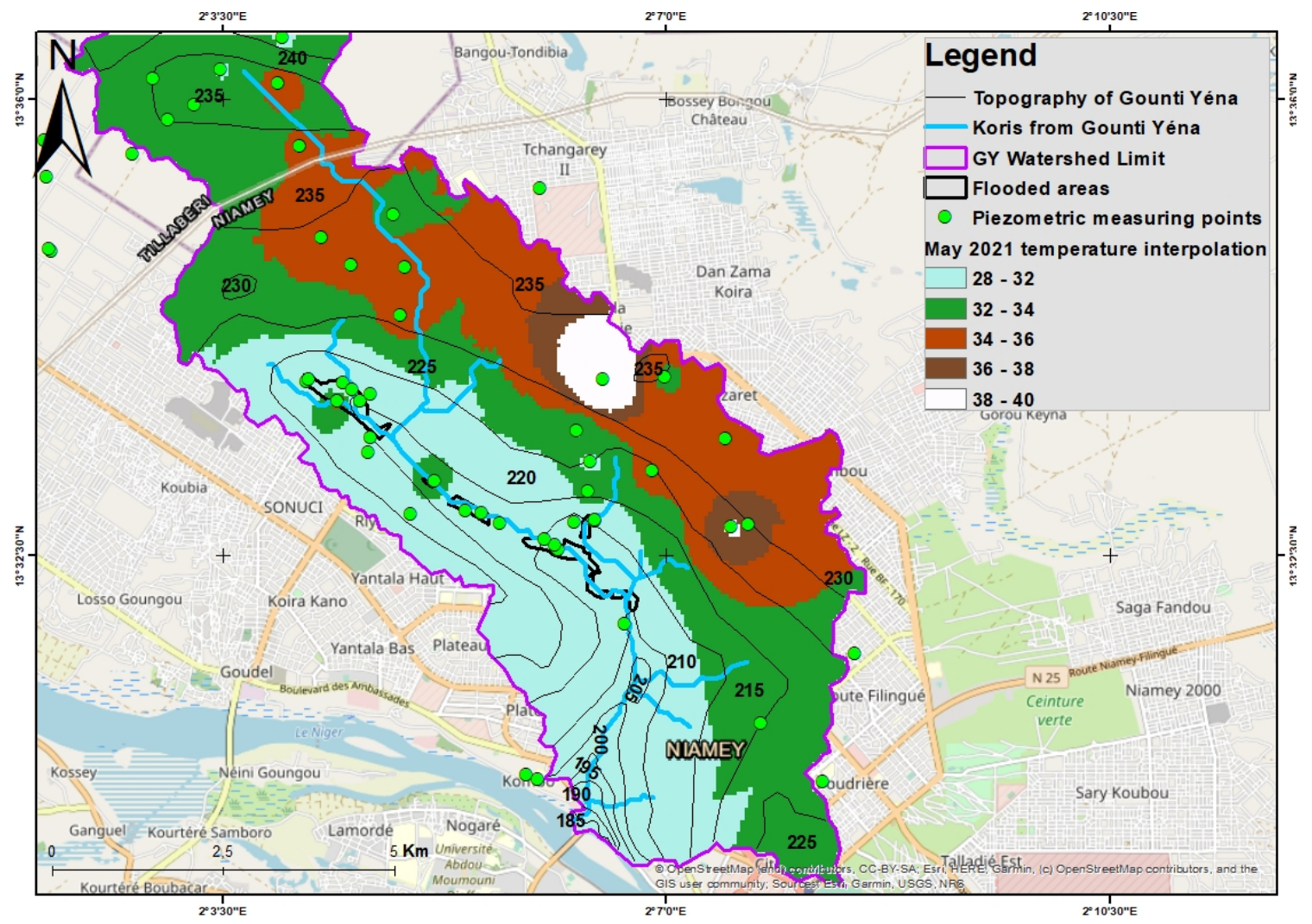

Figure 6. Temperature map in low water.

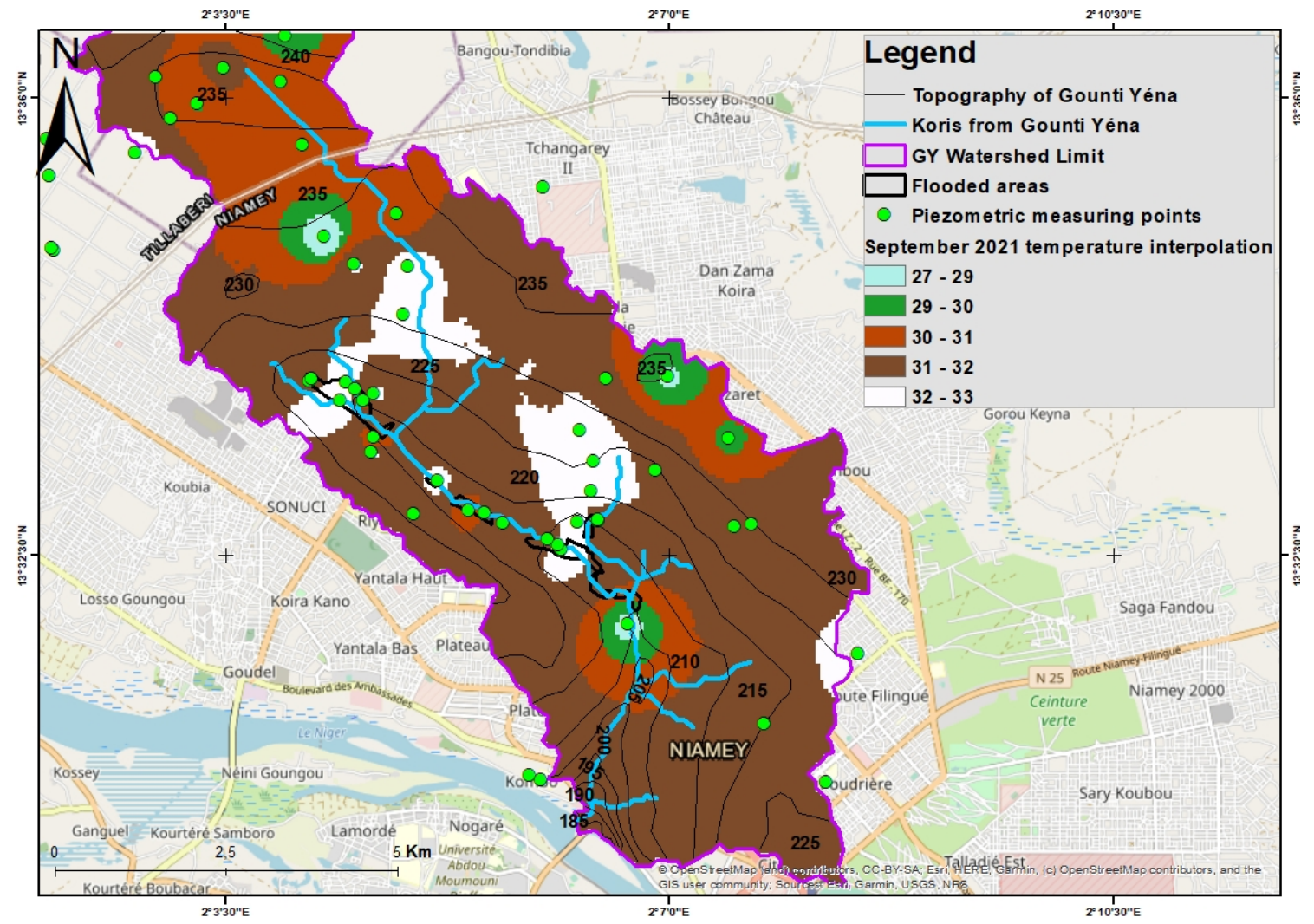

Figure 7. Temperature map in high water. 
are observed in the CT3 wells) In this study, temperatures ranged from $28^{\circ} \mathrm{C}$ to $40^{\circ} \mathrm{C}$ in low water (Figure 6) and from $27^{\circ} \mathrm{C}$ to $33^{\circ} \mathrm{C}$ in high water (Figure 7 ). However, high temperatures favor the development of microbiological activity, which is often the cause of pollution.

\subsubsection{Electrical Conductivity}

Conductivity allows a quick and approximate evaluation of the overall mineralization of the water. Conductivity is measured by measuring the conductance of water between 2 metal electrodes, it is the inverse of electrical resistivity. Deep aquifers are characterized by high conductivity and that of groundwater is low, with a median of $198 \mu \mathrm{s} / \mathrm{cm}$ and extreme values of 30 and $501 \mu \mathrm{s} / \mathrm{cm}$ [36]. After this characterization of [37] not having taken into account the character or at least the behavior of the water table in an urban environment, [2] also states that the free water table of the Continental Terminal appears to be poorly mineralized (generally less than $100 \mu \mathrm{s} / \mathrm{cm}$ ). While since 1997, [39], had specified the range of variation of the conductivity of the Continental Terminal aquifer in Niamey which is quite wide (10 to $6800 \mu \mathrm{s} / \mathrm{cm}$ ). The results found in this study are consistent with this variation and are close to those obtained by [40] fluctuating from 400 to $2400 \mathrm{us} / \mathrm{cm}$ and [41] to state that these conductivities can exceptionally reach values of $7000 \mathrm{us} / \mathrm{cm}$.

Conductivities vary from 20 to $1500 \mu \mathrm{s} / \mathrm{cm}$ in the dry season (Figure 8) and from 20 to $3000 \mu \mathrm{s} / \mathrm{cm}$ in the rainy season (Figure 9). The increase in the conductivity of the water of the Gounti Yéna basin is due to the intense evaporation that induces a strong mineralization of the water in salts, which increases the conductivity of the water [41] on the one hand and on the other hand this electrical conductivity increases with the piezometry of the water table. The high mineralization can be explained by the infiltration into the water table of rainwater that has solubilized domestic waste, or of dirty water from latrines and poorly maintained gutters.

On the isoconductivity maps, it can be seen that the dissolved salt concentration nuclei correspond to areas with high population density, i.e., old neighborhoods such as Boukoki, Deyzeibon, Zongo, South Lazaretto, etc. This relationship between concentration of dissolved salts and population density is also clearly seen in the new settlement areas where the value of the latter is lower, such as the Karsamba district, upstream of the basin. It appears that in 1986, the whole of the urbanized left bank is an area of low electrical conductivity, less than $500 \mu \mathrm{s} / \mathrm{cm}$ [38], this value corresponds today to that of the semi-urbanized sector. It is not excluded that in addition to this very important factor of population density the lithological nature of the aquifer influences the concentration of dissolved salts.

\subsection{Chemical Parameters}

\subsubsection{Major Elements \\ 1) Calcium}




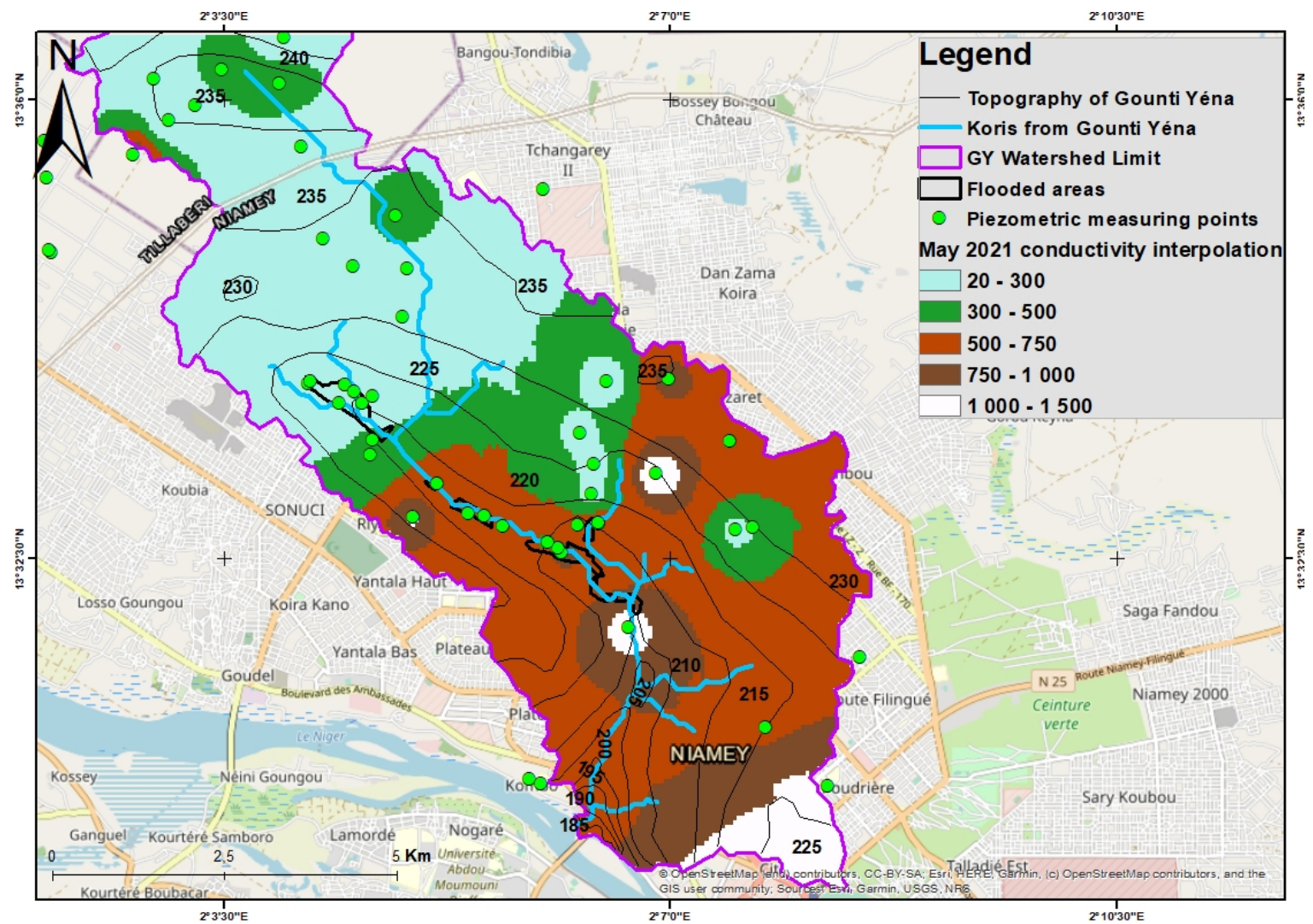

Figure 8. Conductivity in low water.

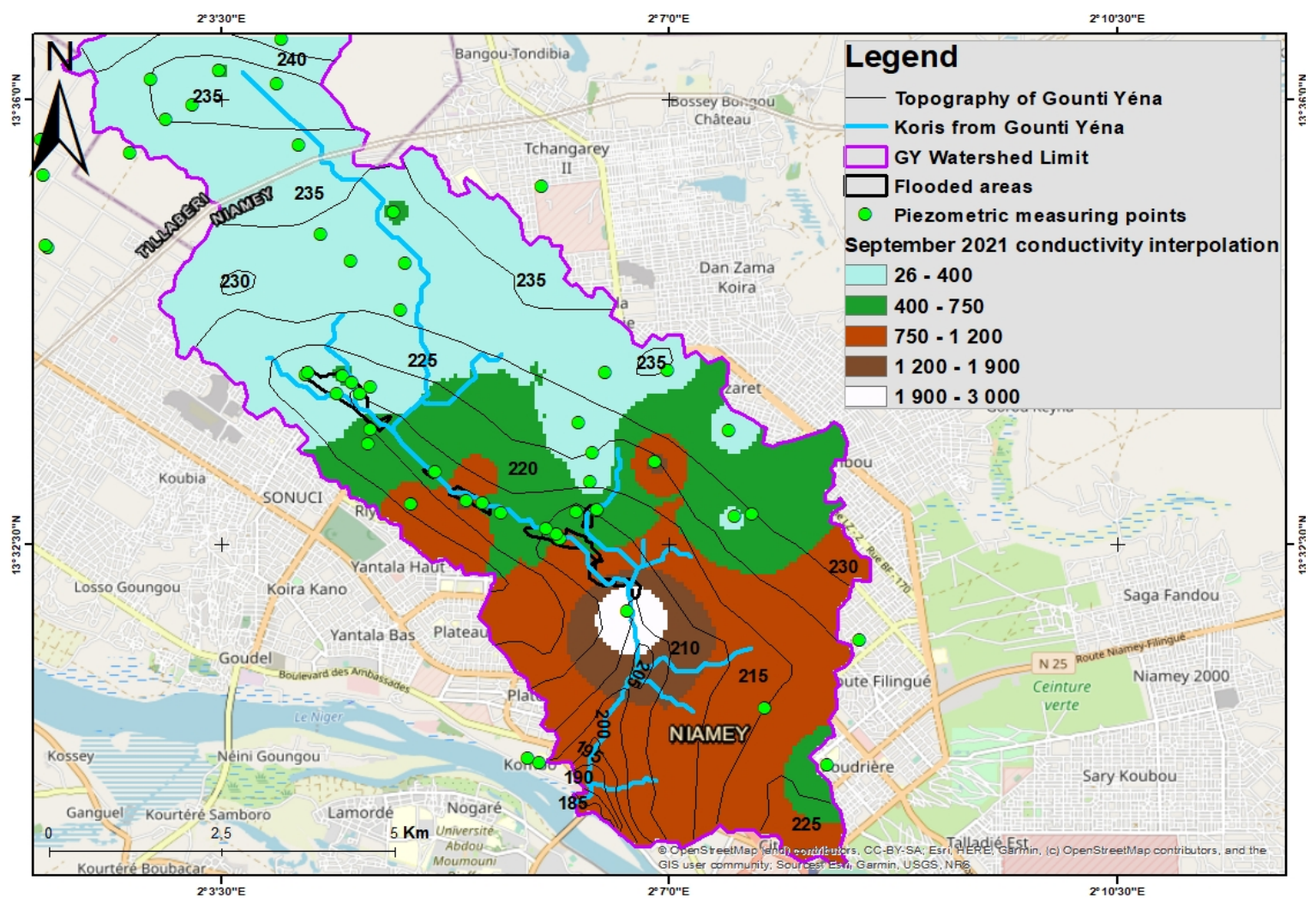

Figure 9. Conductivity map in high water. 
Calcium is an alkaline earth metal that is extremely common in nature, especially in limestone rocks in the form of carbonates. It is the major component of water hardness. The arrival of the infiltration water corresponds to a decrease in the calcium content. We notice through Figure 10 that as soon as there is a rainfall, the level of the water table rises and the calcium content drops. These contents varying from 0 to $42 \mathrm{mg} / \mathrm{l}$ (Figure 10) are below the standards fixed by the WHO.

\section{2) Magnesium}

Magnesium is the second significant element of water hardness after calcium. The levels are low for groundwater with a maximum of $9.5 \mathrm{mg} / \mathrm{l}$ (Figure 11), the WHO standard being set at $50 \mathrm{mg} / \mathrm{l}$.

\section{3) Sodium}

Sodium salts (e.g. sodium chloride) are present in virtually all foods (the main source of exposure) and in drinking water. Although sodium levels in drinking water are generally less than $20 \mathrm{mg} / \mathrm{l}$, they can be much higher in some countries. Levels of sodium salts in air are normally low compared to levels measured in food or water. It should be noted that some water softeners can significantly increase the sodium content in drinking water. These levels increase inversely with the rise in the water table (Figure 12).

The Sodium absorption rate (SAR) of the different samples and their conductivities (Figure 13) demonstrate that they have a low alkalizing power through the Riverside diagram, which implies that these water can then be used on any type of soil in irrigated crops without danger of alkalization of the soils used.

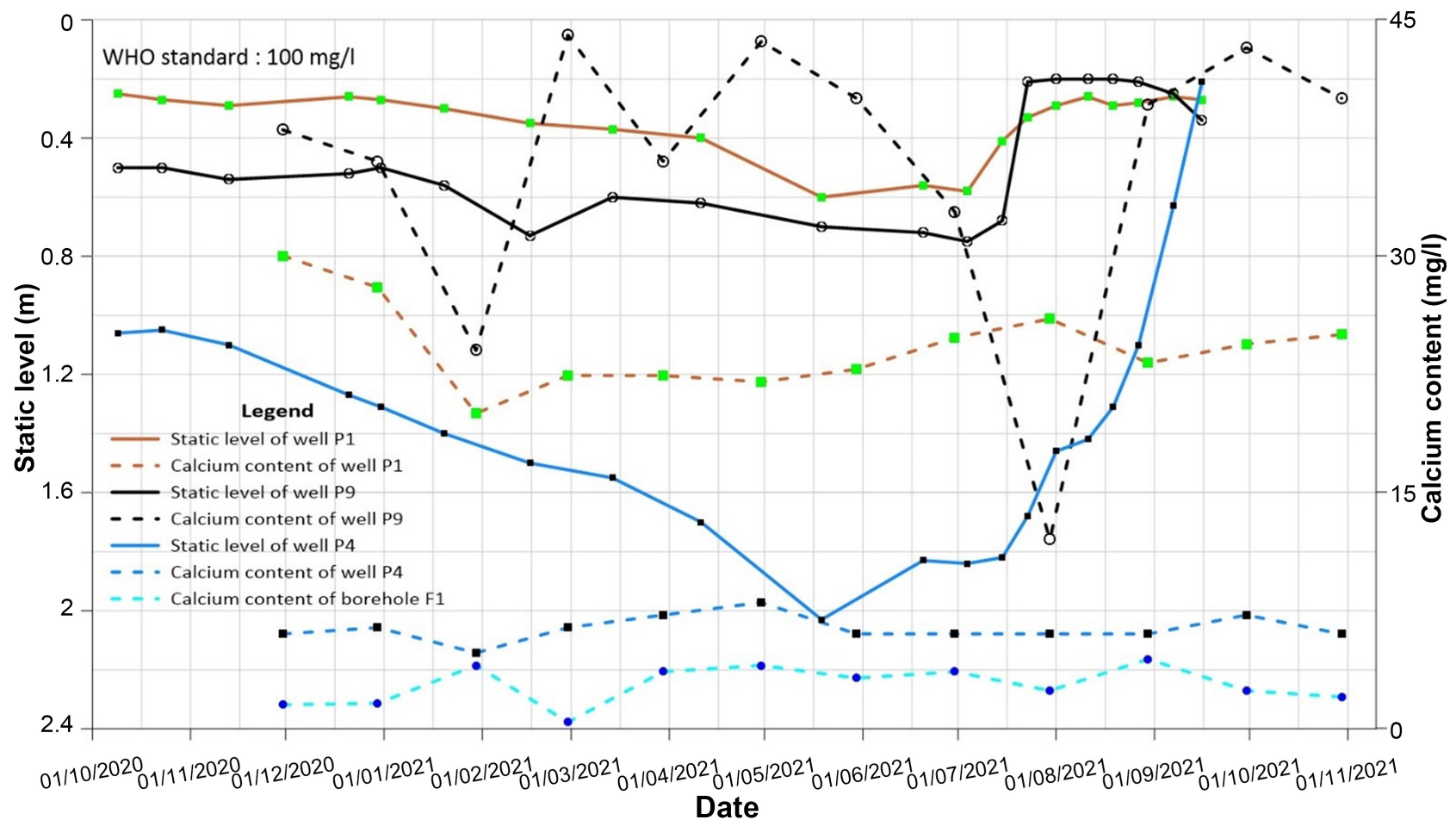

Figure 10. Variation of Calcium content in GY groundwater as a function of piezometry. 


\section{4) Nitrite}

Nitrite is produced either by incomplete oxidation of ammonia or by reduction

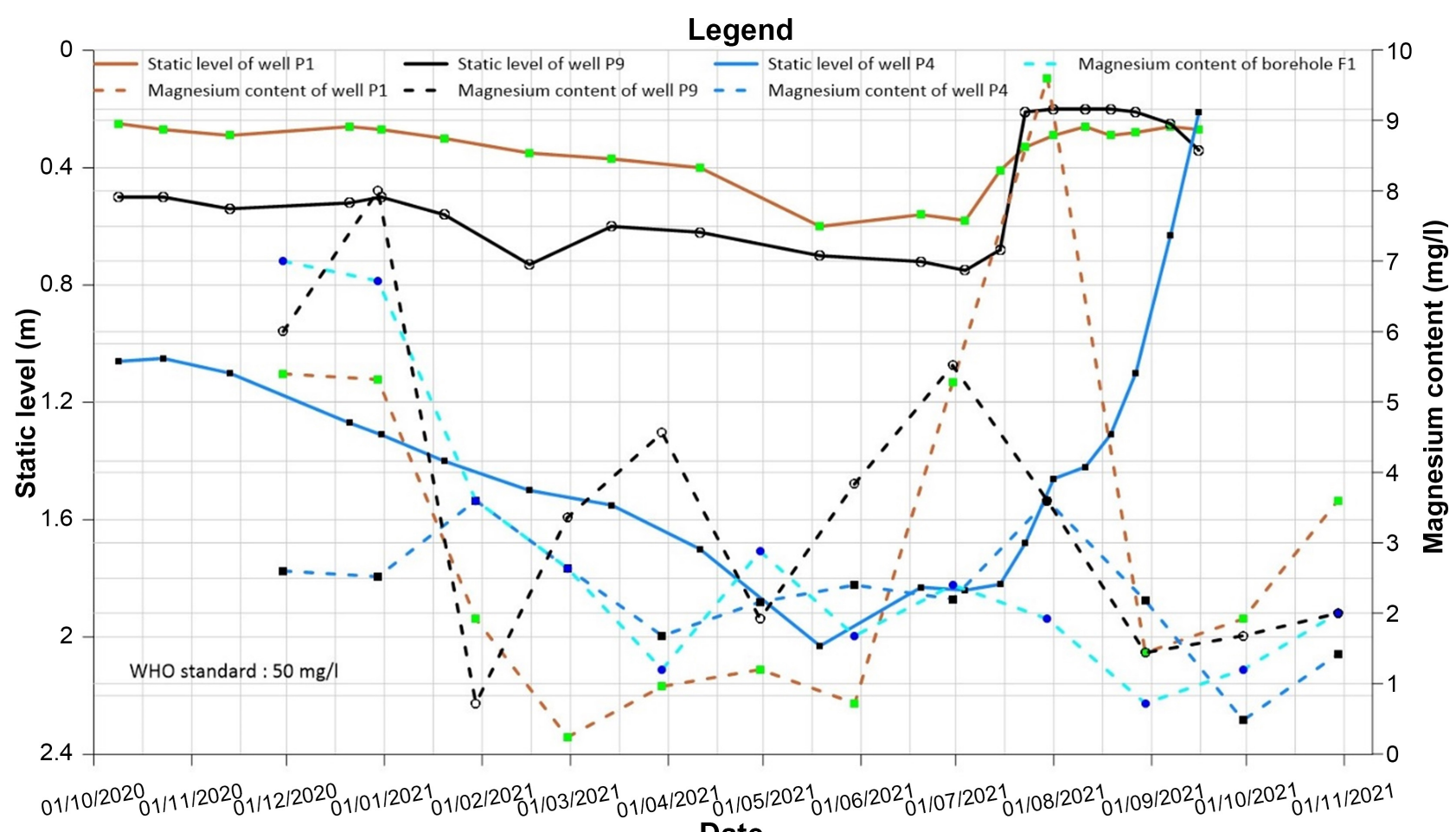

Figure 11. Variation of Magnesium content in GY groundwater according to piezometry.

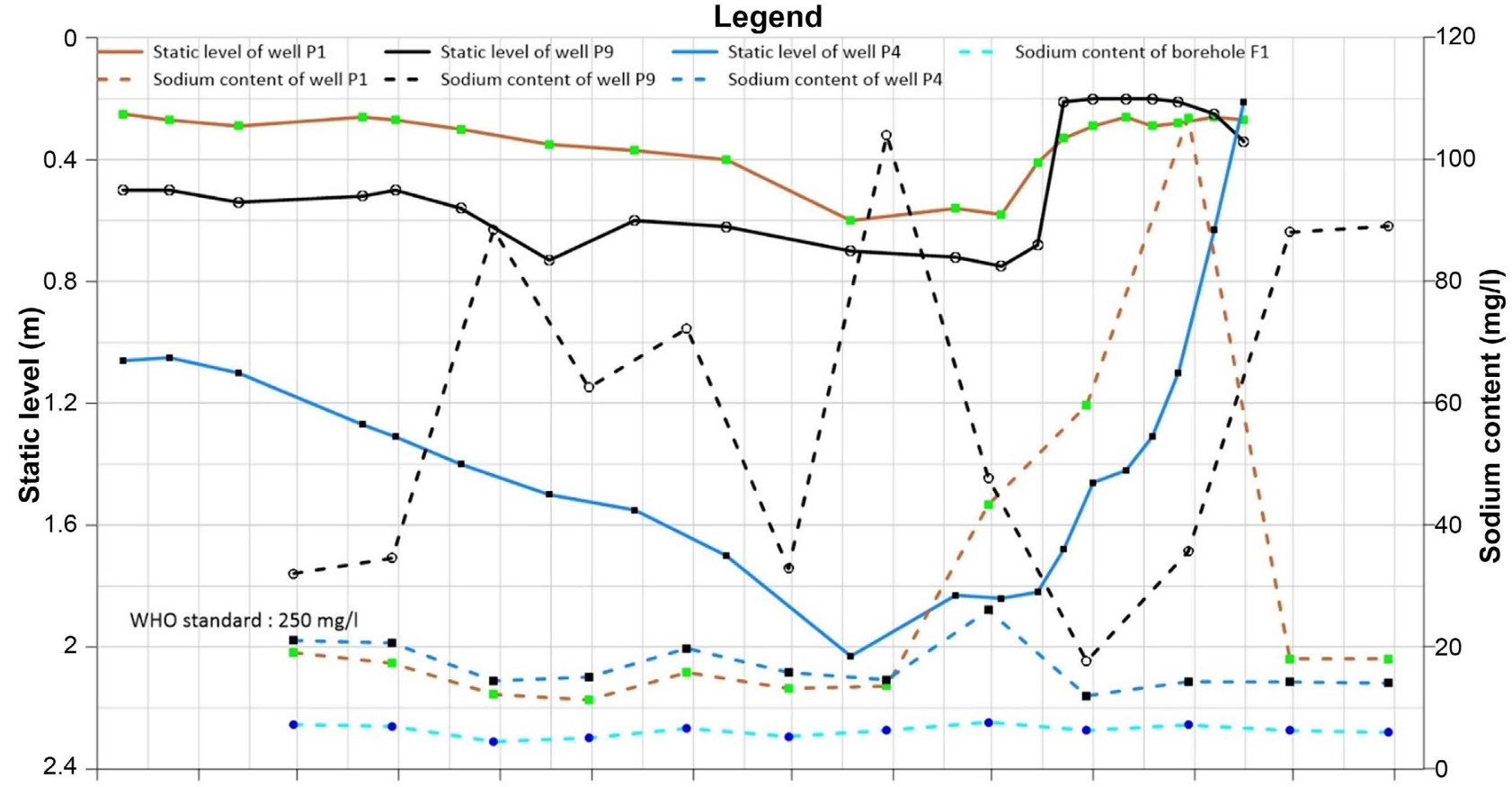

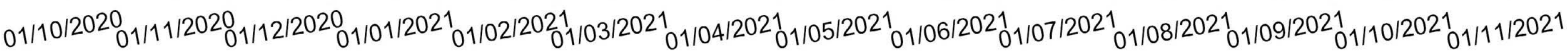

Date

Figure 12. Variation of Sodium content of GY groundwater with piezometry. 


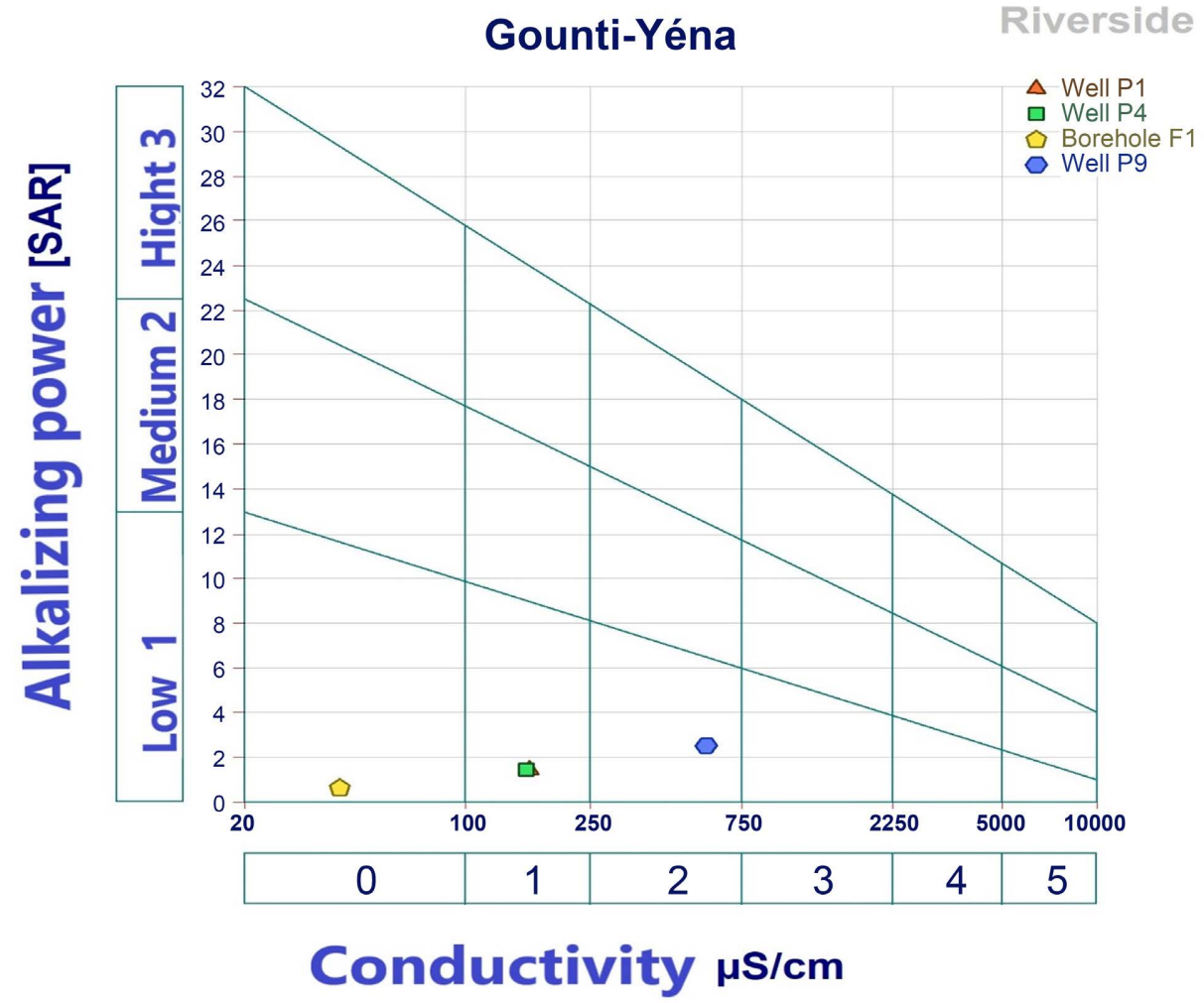

Figure 13. Suitability of water for irrigation.

of nitrate under the influence of denitrifying action. Water containing nitrite is to be considered as suspect. The nitrite ion $\left(\mathrm{NO}_{2}^{-}\right)$is usually not detected in significant concentrations except in reducing environments, since nitrate represents the most stable oxidation state. Nitrite can be formed by microbial reduction of nitrate and, in vivo, by reduction of ingested nitrate. Nitrite can also result from a chemical reaction in distribution pipes produced by bacteria of the genus Nitrosomonas, when low-oxygen drinking water containing nitrate stagnates in galvanized steel pipes or when chlorination is used to maintain a disinfectant residual. Drinking water can be a major contributor to the ingestion of nitrates and occasionally nitrites. In the case of bottle-fed neonates, drinking water may be the primary external source of nitrate and nitrite exposure. The concentration changes in proportion to the piezometric fluctuation (Figure 14). As the WHO standard is $3 \mathrm{mg} / \mathrm{L}$, all measured values remain below this.

\section{5) Nitrates}

Nitrate ion $\left(\mathrm{NO}_{3}^{-}\right)$is naturally present in the environment and is an important plant nutrient. It is present in varying concentrations in all plants and is one of the links in the nitrogen cycle. Nitrates are rapidly absorbed by ingestion of vegetables, meat or water and are finally excreted in the urine. In humans, about $25 \%$ of ingested nitrate is found in saliva, of which $20 \%$ is converted to nitrite by bacteria in the mouth. All forms of nitrogen are likely to be the source of nitrates through a biological oxidation process. The levels are higher in dry periods than in rainy ones. This temporal evolution of $\mathrm{NO}_{3}$ has also been observed in the 


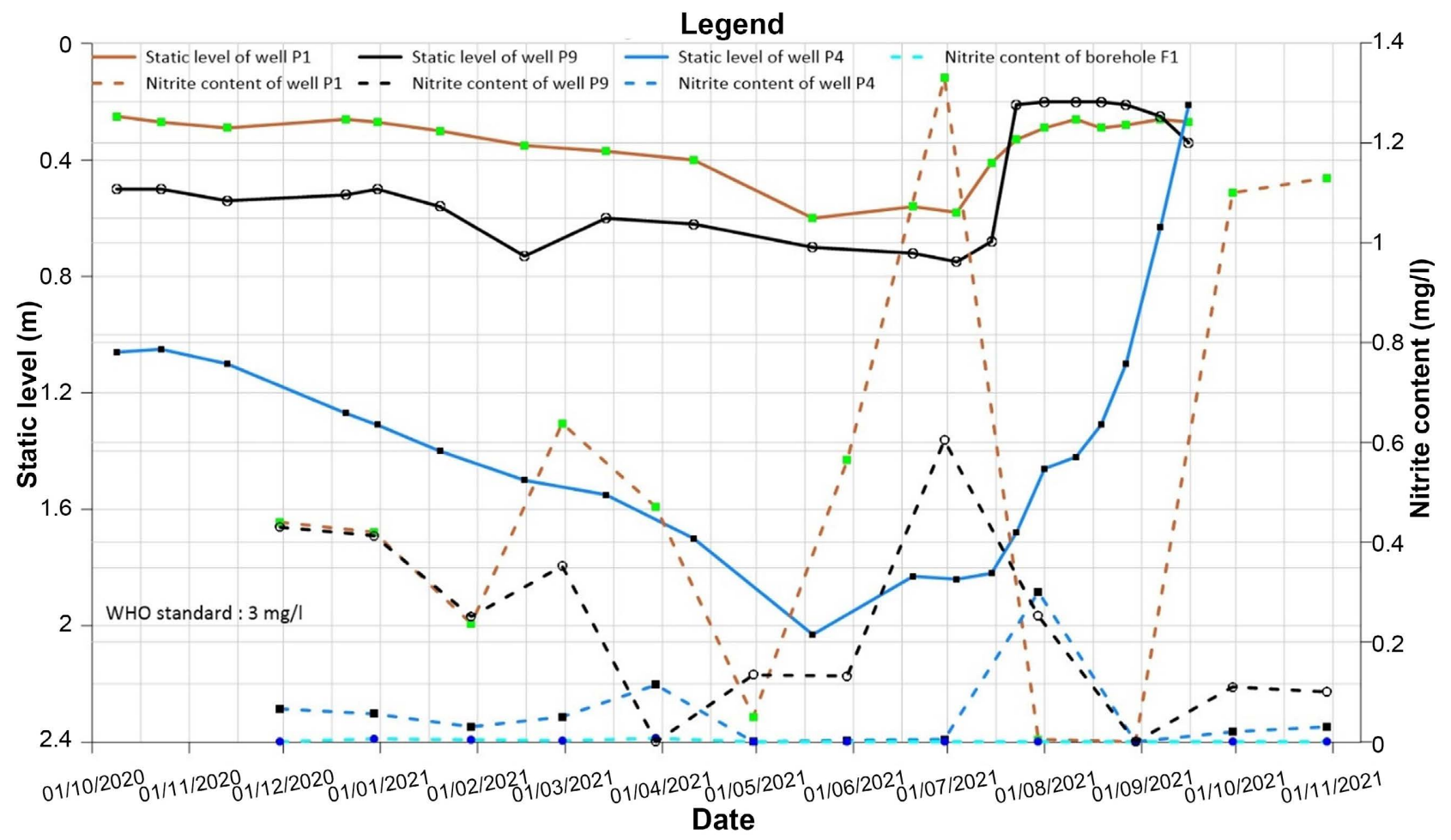

Figure 14. Variation of Nitrite as a function of piezometry.

works of several authors. However, all the values are below the WHO norms except for wells P1 and P4 in March 2021 (Figure 15), which see their levels exceed the WHO limit. Nitrate inputs could be linked to the leaching of agricultural soils upstream of the watershed and the discharge of city wastewater in contact with the groundwater.

The levels show pollution of organic origin linked to the infiltration of water from cesspits. This infiltration is generally accentuated during the flood with the general rise of the water table; these pollutant transfers are weak during the low water period, therefore these Mars levels seem abnormal.

The distribution of Nitrates remains very variable in space and time, despite factors favorable to an enrichment of water in nitrates, it appears that most of the water points have a concentration below the limit of potability set by the WHO for other periods especially in an environment of strong interconnected septic tanks groundwater like the Gounti Yéna.

\section{6) Potassium}

Potassium is a mineral salt that plays an essential role in the proper functioning of the body. On the other hand, a very high level of potassium in the blood can be dangerous and have serious consequences (for example serious cardiac problems). It is an essential element for humans and is rarely, if ever, present in drinking water at levels that could present a risk to human health. The recommended daily intake is over $3000 \mathrm{mg}$. Potassium is widely distributed in the environment, including all natural water. It may also be present in drinking water as a result of the use of potassium permanganate as an oxidant in water treatment. 


\section{Legend}

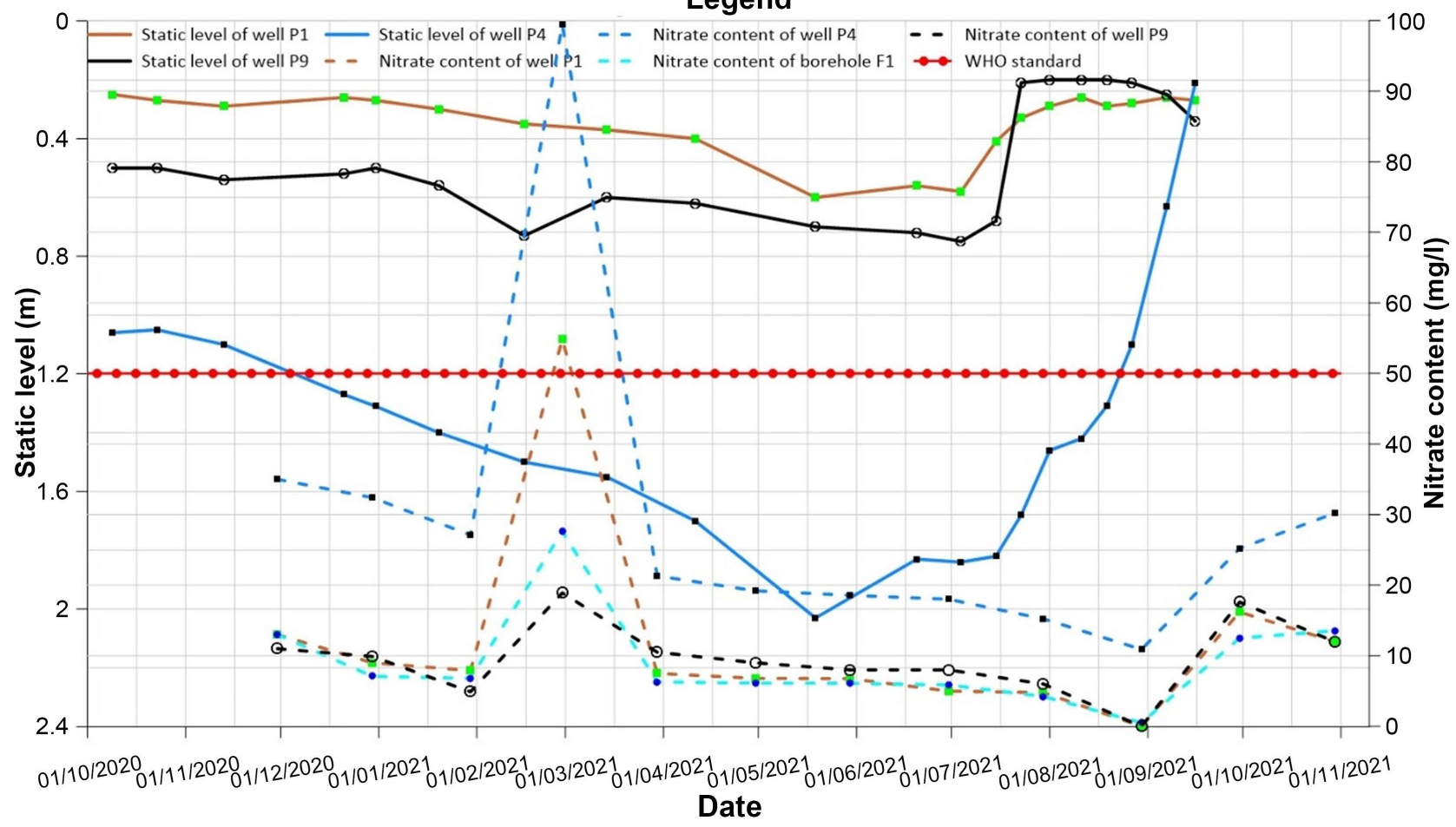

Figure 15. Variation in Nitrate as a function of piezometry.

In some countries, potassium chloride is used in ion exchange columns for domestic water softening instead of or in mixture with sodium chloride, so that potassium ions are exchanged with calcium and magnesium ions.

Levels of this element are highest at the beginning of the rainy season, just at the first reaction of the water table (Figure 16). The fact that these levels are higher at the beginning of the season indicates that external inputs (atmospheric and anthropogenic) are more important at this period. We note levels exceeding the WHO standards, especially during the rainy period.

\section{7) Bicarbonates}

There is no WHO standard for this element, but a high concentration of bicarbonates gives a salty taste to the water. These levels are probably due to the low dissolution of carbon dioxide in the soil. They are lower during the hot dry period, especially in February, March, April and May (Figure 17).

\section{8) Sulfates}

Sulfates are naturally present in many minerals and are marketed mainly to the chemical industry. Their presence in water comes from industrial waste and atmospheric deposition. However, the highest levels are usually found in groundwater and are naturally occurring. In general, the average daily intake of sulfates from drinking water, air and food is about $500 \mathrm{mg}$, with food being the major source. Sulfate levels are low, and levels recorded throughout the study period do not exceed the limited standard [13]. The variation in these levels is also consistent with the piezometry (Figure 18).

9) Chlorides 


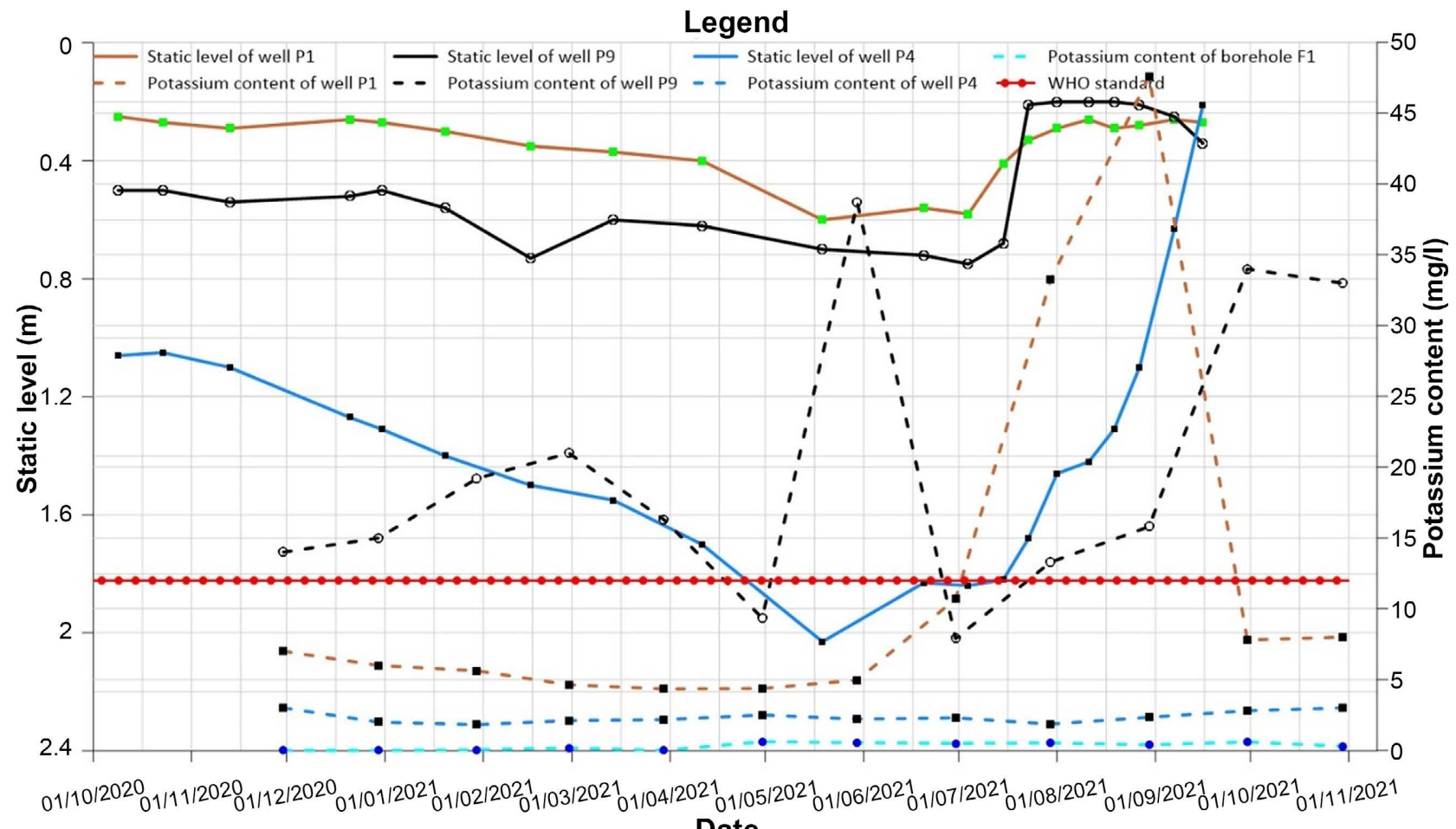

\section{Date}

Figure 16. Variation in Potassium as a function of piezometry.

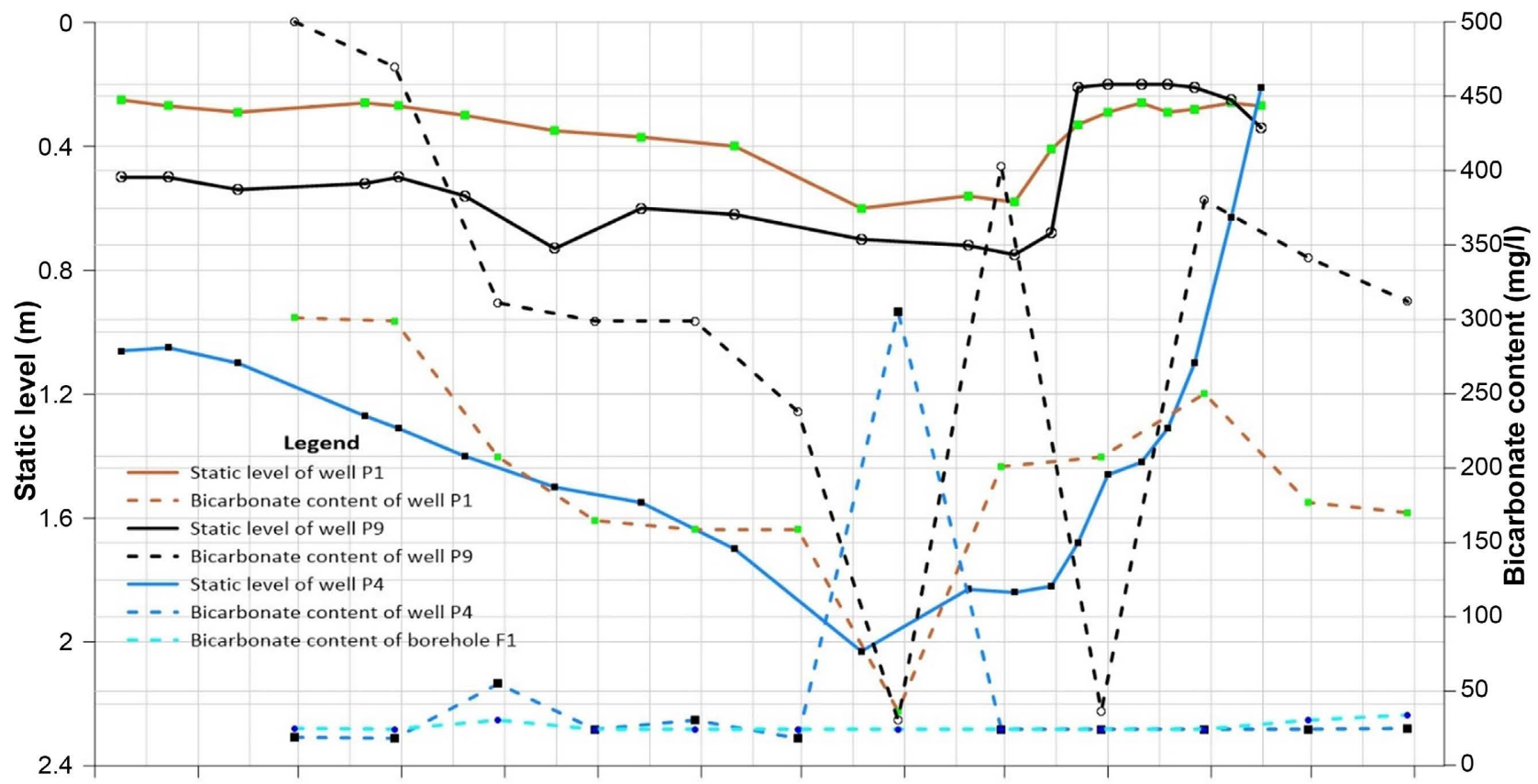

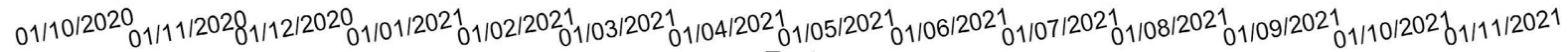

Date

Figure 17. Variation of bicarbonate as a function of piezometry.

Chloride in drinking water comes from natural sources, wastewater and industrial effluents, urban discharges containing road salt, and saltwater intrusions. No health-based guideline values are proposed for chloride in drinking water. 


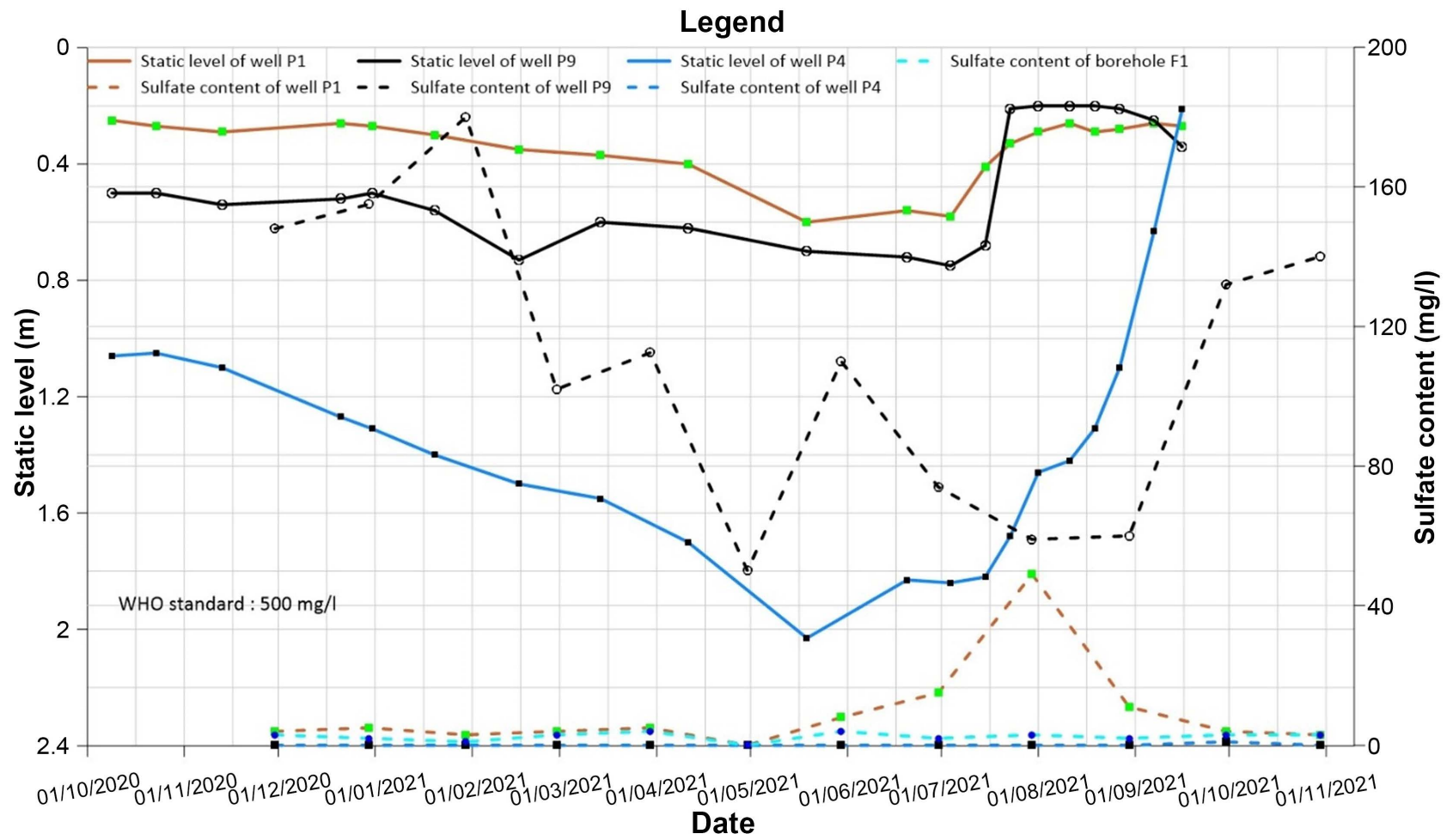

Figure 18. Variation of sulphate content as a function of piezometry.

The main source of chloride exposure for humans is the addition of salt to food, and intake from this source is usually significantly greater than from drinking water. The chloride ion is never absorbed by geological formations, it is a special element. High chloride concentrations are related to water pollution. The concentrations of this element are heterogeneous (Figure 19) with an almost similar evolution of the curves (piezometry-chloride content).

\subsubsection{Heavy Metals}

Heavy metals such as lead, cadmium, cyanides, mercury, etc. are dangerous, even in trace amounts.

\section{1) Lead}

The standard set by the WHO is $0.01 \mathrm{mg} / \mathrm{L}$ and no trace of lead has been detected in the various analyses.

\section{2) Ammonium}

The term ammonia includes both non-ionized $\left(\mathrm{NH}_{3}\right)$ and ionized $\left(\mathrm{NH}_{4}^{+}\right)$species. Ammonia in the environment is generated by metabolic, agricultural and industrial processes; it can also come from disinfection with chloramine. Intensive livestock production can result in much higher levels in surface water. Ammonia contamination can also come from the lining of cement mortar pipes. Ammonia in water is an indicator of possible bacterial contamination or pollution from sewage or animal waste. Ammonia in drinking water does not have a direct impact on health, therefore no guideline values are proposed. However, according to WHO, concentrations should not exceed $0.003 \mathrm{mg} / \mathrm{l}$. Figure 20 


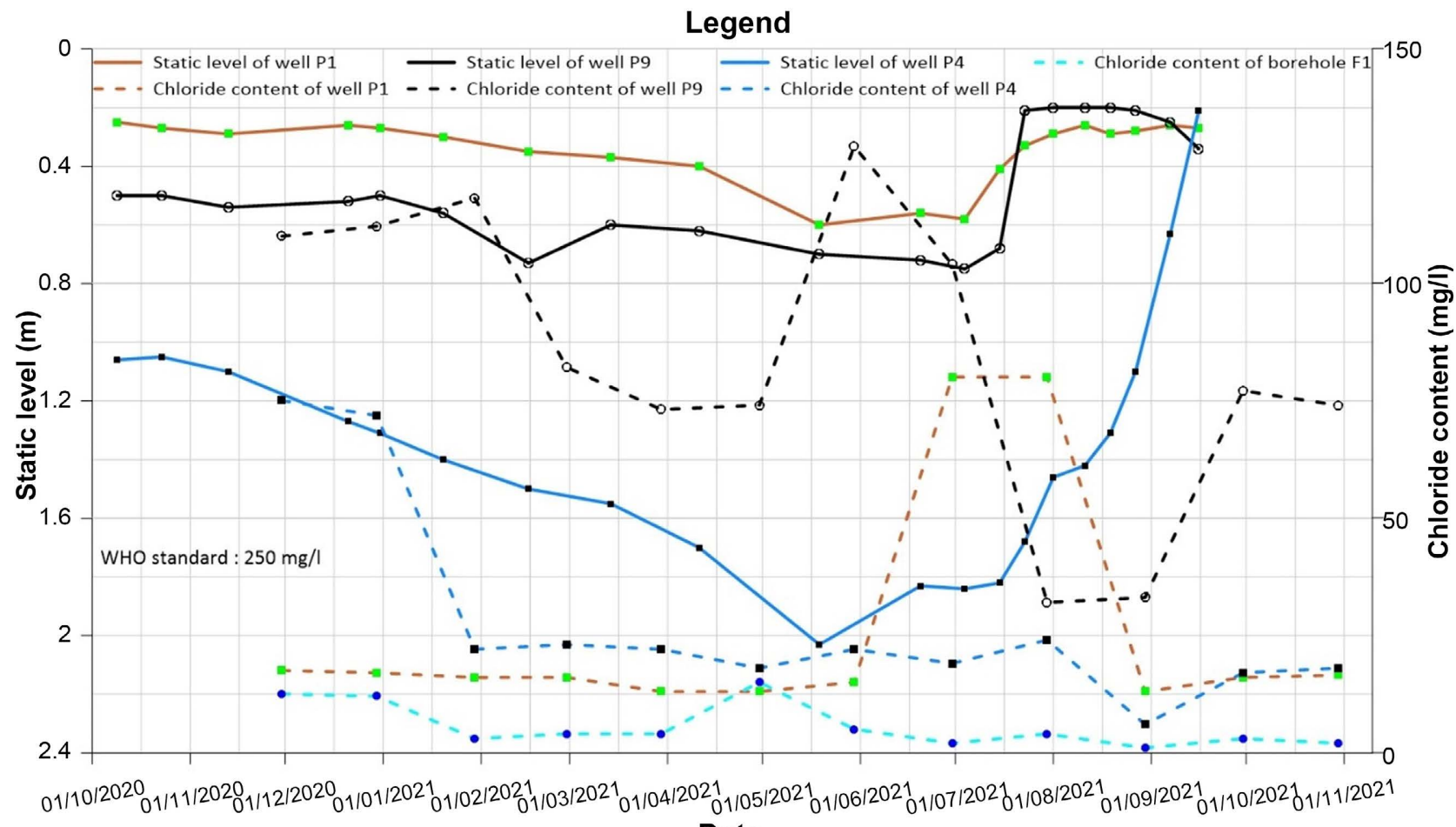

Figure 19. Variation of the chloride as a function of piezometry.

\section{Legend}

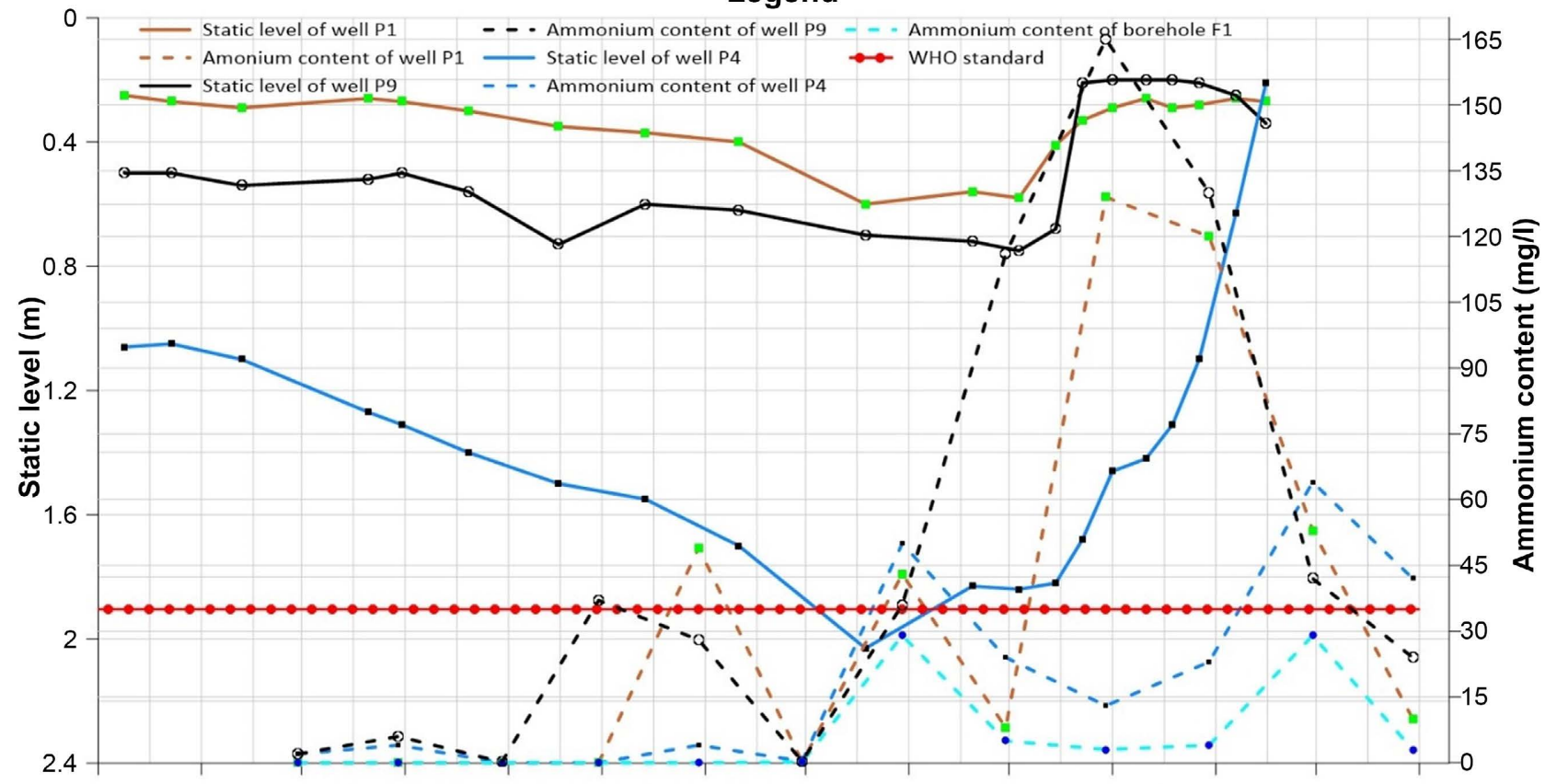

$01 / 10 / 2020{ }_{01 / 1 / 1 / 2020}{ }_{01 / 1 / 2 / 2020}{ }_{01 / 01 / 2021}{ }_{01 / 02 / 2021}{ }_{1 / 103 / 2021}{ }_{01 / 04 / 2021}{ }_{01 / 05 / 2021}{ }_{01 / 06 / 2021}{ }_{01 / 07 / 2021}{ }_{01 / 08 / 2021}{ }_{01 / 09 / 2021}{ }_{01 / 10 / 2021}{ }_{1 / 1 / 1 / 2021}$

\section{Date}

Figure 20. Variation in ammonium content as a function of piezometry.

shows levels exceeding this limit, especially during the rainy season. An increase in these concentrations is noted in proportion to the rise in the water table. This 
increase in this period would be related to the bacterial decomposition of nitrogenous organic matter due to the slight decrease in dissolved $\mathrm{O}_{2}$ levels recorded in these periods. Ammonium is absorbed preferentially when the algae have $\mathrm{NH}_{4}^{+}$and $\mathrm{NO}_{3}^{-}$simultaneously, which explains the low levels measured in the dry season, without neglecting the part of nitrification because the environment is well oxygenated.

According to [9], the ammonia assay gave very low results in the wells, but high to very high in the surface water (Gounti-Yéna and pond). This ammonia pollution has also been demonstrated by [38] on a well in a garden in Gounti-Yéna.

\section{3) Cadmium}

Cadmium enters the environment through wastewater; diffuse pollution is due to contamination by fertilizers and local air pollution. Contamination of drinking water can also be caused by impurities in zinc used in galvanized pipes and welds and in some metal fittings.

Cadmium accumulates primarily in the kidneys and has a long half-life in humans (10 to 35 years). Cadmium has been shown to be carcinogenic when inhaled and IARC has classified cadmium and its compounds as Group 2A (probably carcinogenic to humans). However, there is no evidence of oral carcinogenicity of cadmium and no clear evidence of genotoxicity. The kidney is the primary target organ for cadmium toxicity. All values of the measurements are zero, thus below the WHO standards (Figure 21).

\section{4) Cuivre}

Cuivre is both an essential nutrient and a contaminant of drinking water. Levels in running water or after complete purging tend to be low, while in samples

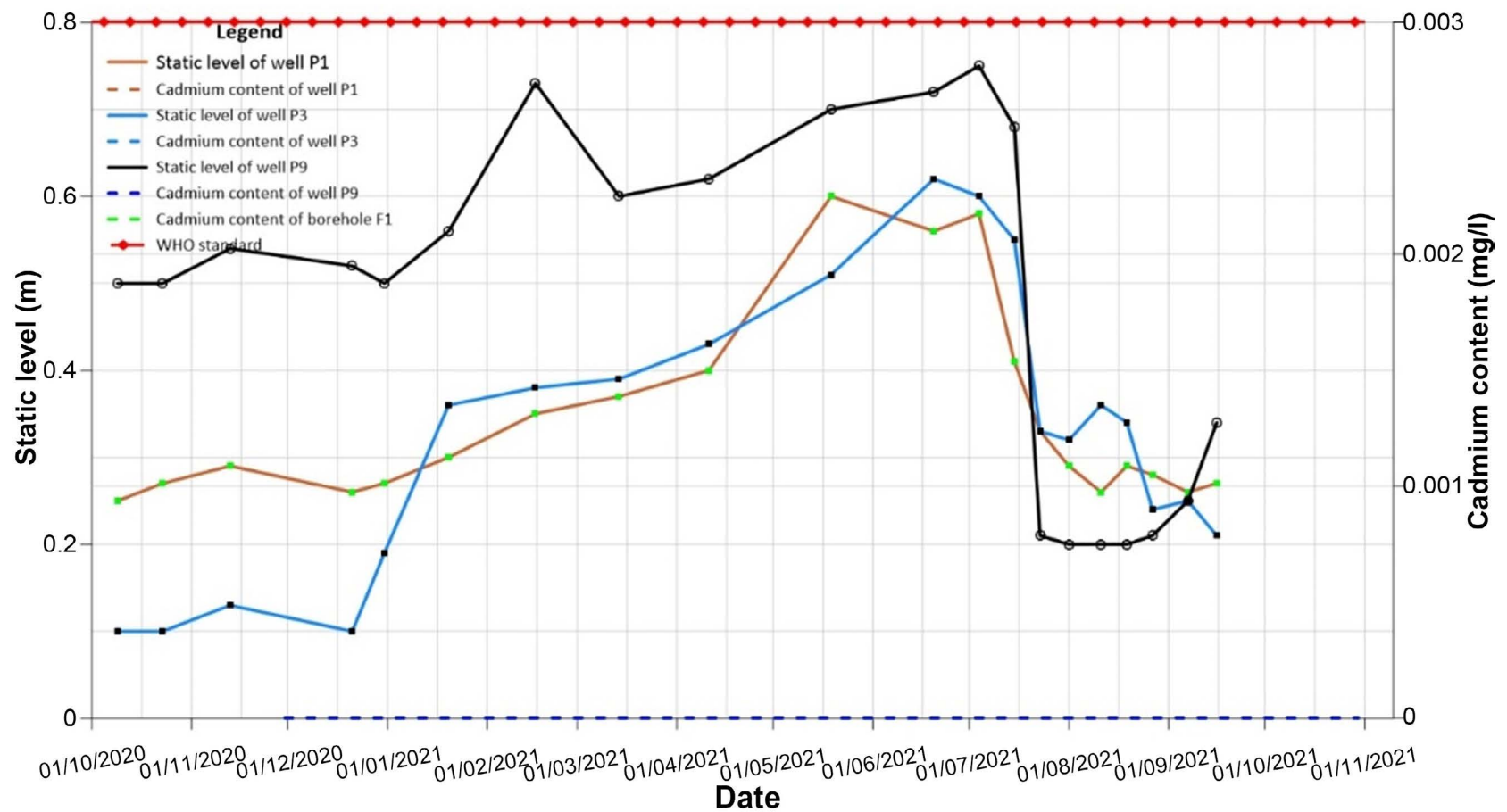

Figure 21. Variation of cadmium as a function of piezometry. 
of stagnant water (Figure 22) or partially purged systems, concentrations are more variable and can be significantly higher (frequently greater than $1 \mathrm{mg} / \mathrm{l}$ ). Consumption of stagnant water or water from partially purged distribution systems can significantly increase total daily exposure to copper. No values during the monitoring period exceeded the WHO standard.

\section{5) Nickel}

The contribution of water to nickel exposure can be significant when, for example, the level of pollution is high and non-resistant materials are used in well construction. The most common effect of nickel in the general population is allergic contact dermatitis. The WHO standard is $0.07 \mathrm{mg} / \mathrm{l}$ and the measured levels in the groundwater (Figure 23) are well below this, and the levels also fall during the rainy season.

\section{6) Chromium}

Chromium is widely distributed in the earth's crust. It has a range of valences from +2 to +6 . Chromium (III) is an essential nutrient. The maximum value accepted by the WHO is $0.05 \mathrm{mg} / \mathrm{l}$. All measurements are heterogeneous and for a very large part exceed the WHO standards (Figure 24).

\section{7) Zinc}

Zinc is an essential trace element found in virtually all foods and drinking water as salts or organic compounds. Although zinc levels in surface water and groundwater do not usually exceed 0.01 and $0.05 \mathrm{mg} / \mathrm{l}$, respectively, concentrations in tap water can be much higher as a result of dissolution of zinc from pipes. The WHO standard is $3 \mathrm{mg} / \mathrm{L}$, and groundwater is well below this (Figure 25).

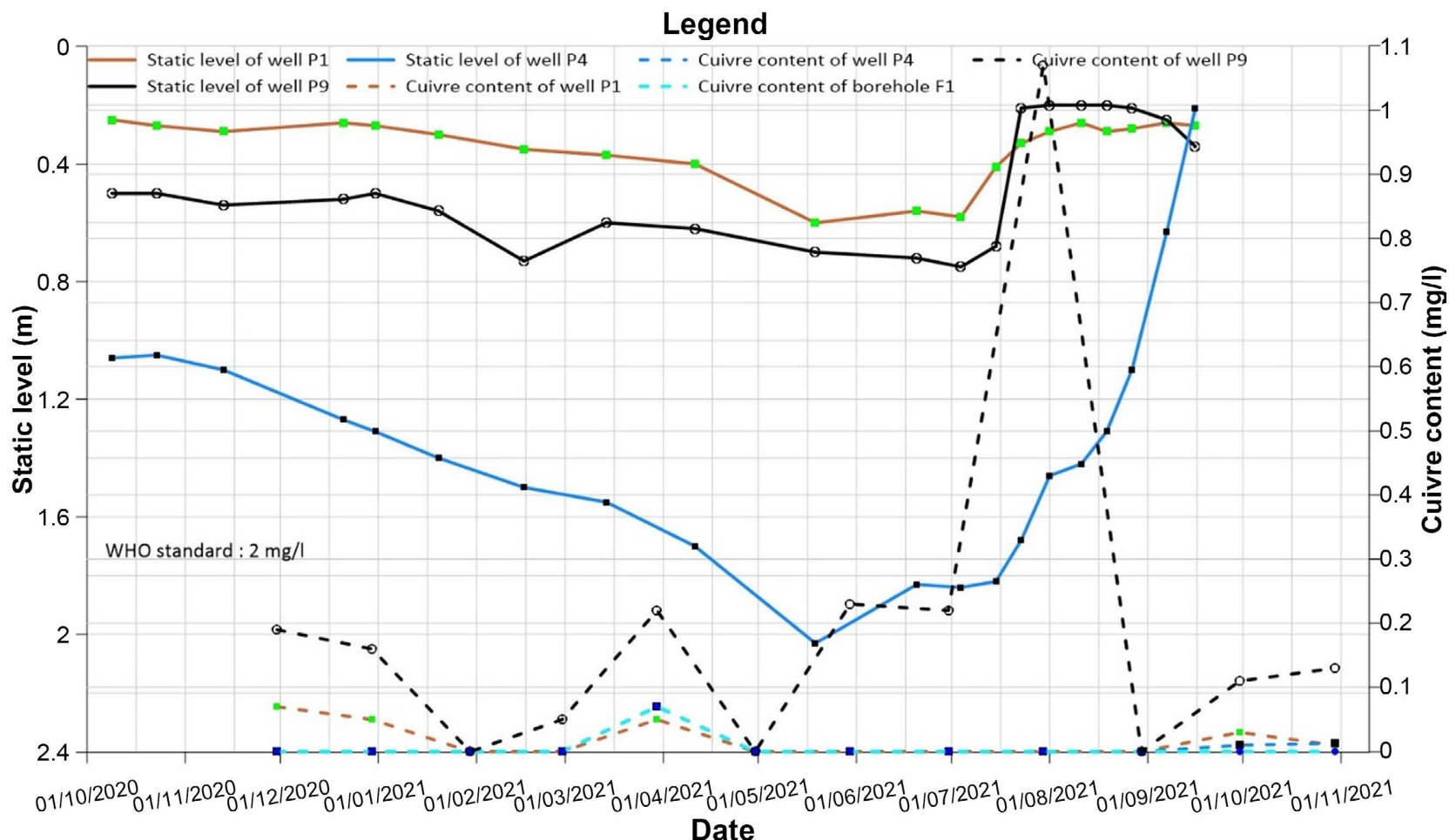

Figure 22. Variation of Cuivreas a function of piezometry. 


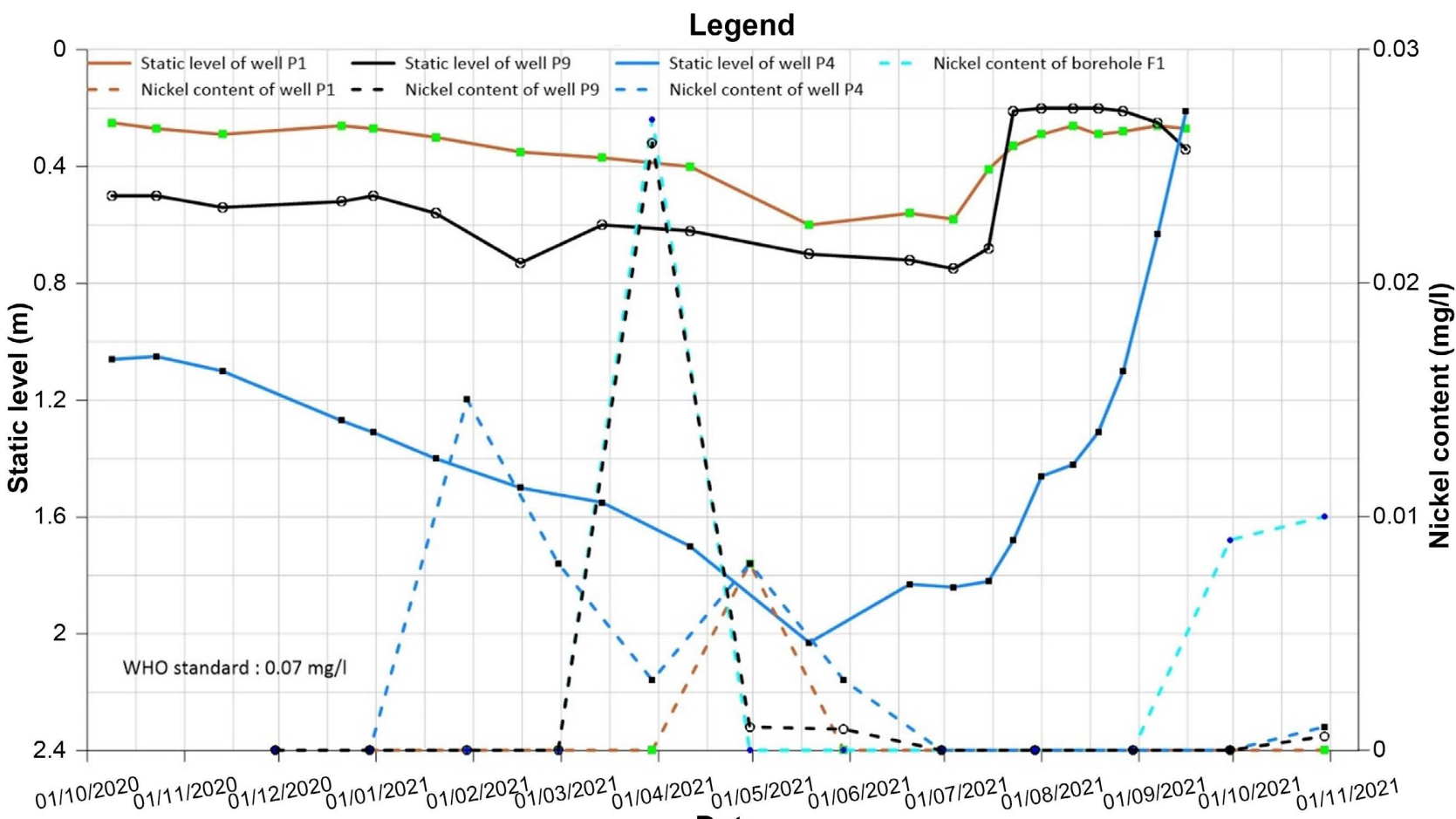

Figure 23. Variation of Nickel as a function of piezometry.

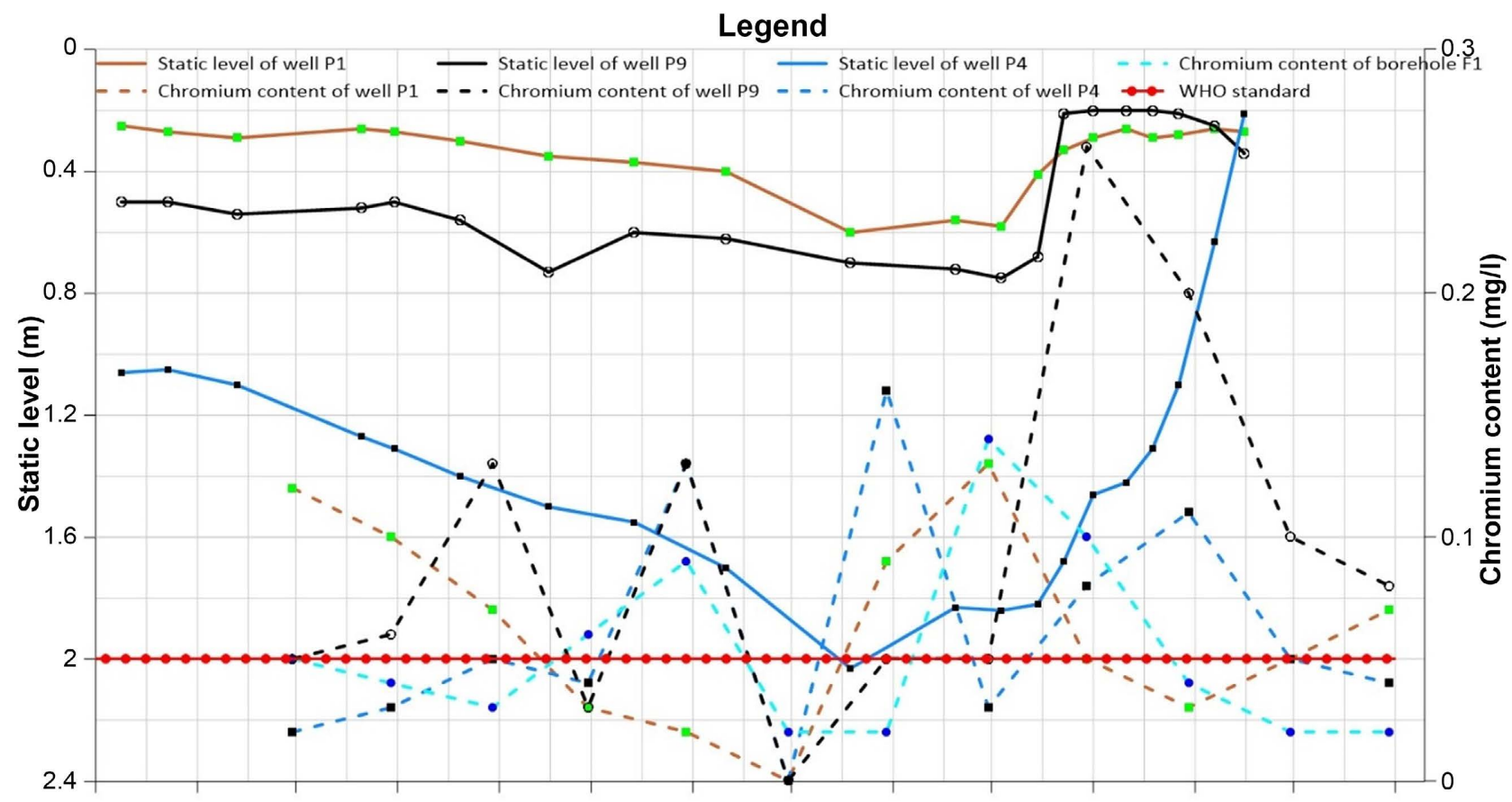

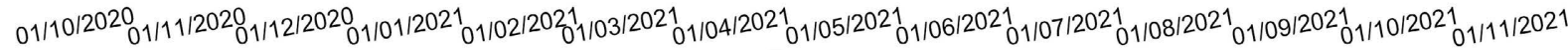

Date

Figure 24. Variation in Chromium as a function of piezometry.

\section{8) Phosphorus}

For phosphorus, the main indicator is the total phosphorus concentration, 


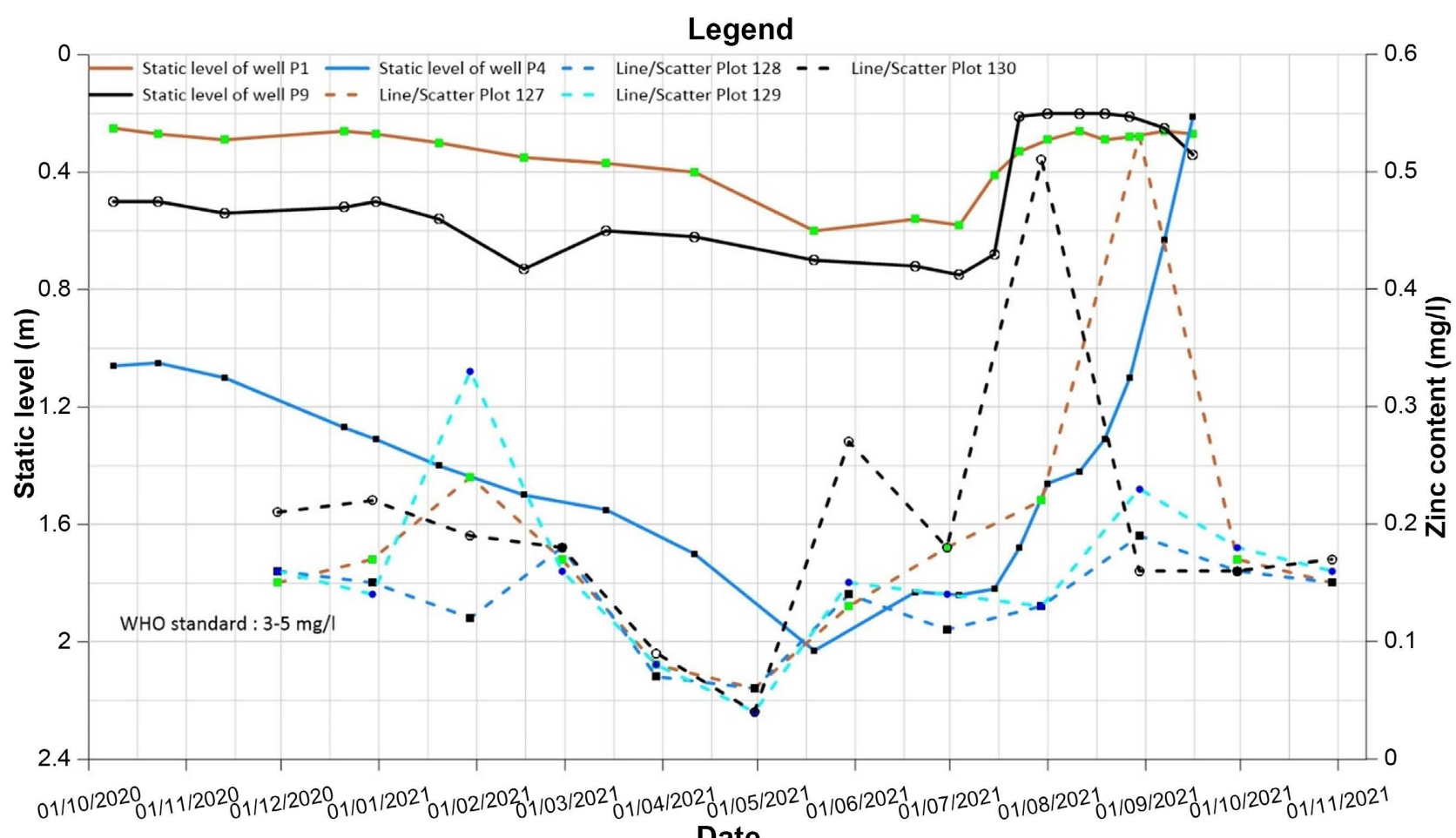

Date

Figure 25. Variation in Zinc as a function of piezometry.

which must not exceed $0.2 \mathrm{mg} / \mathrm{L}$. Phosphorus flows have three origins: collective domestic sanitation, discharges from livestock buildings and phosphorus departures through soil erosion. This last parameter is very difficult to evaluate and depends not only on the type of soil and its phosphorus content, but also on the use of the land and the development of the area. In surface water, phosphorus is essential to plants, but in excessive quantities, it contributes mainly to modifying the biological balance of aquatic environments by causing eutrophication phenomena.

Phosphorus should not be monitored in groundwater because it has no known harmful effects in this environment, but we determined it anyway. For all analyses, high levels are observed in March (Figure 26). This increase in phosphorus concentration in the water of Gounti Yéna basin during this period is due to the increase in organic compounds in the water, which favors a very thorough mineralization of organic matter.

\section{9) Iron}

The presence of iron in domestic water supplies is not desirable for a number of reasons. Iron is a fairly abundant element in rocks. It is soluble as $\mathrm{Fe}^{2+}$ (ferrous ion) but insoluble as $\mathrm{Fe}^{3+}$ (ferric ion).

Iron is one of the most abundant metals in the earth's crust. It is present in natural freshwater at levels between 0.5 and $50 \mathrm{mg} / \mathrm{l}$. The presence of iron in water can promote the proliferation of certain strains of bacteria that precipitate iron. The WHO standard is $0.3 \mathrm{mg} / \mathrm{L}$. Well P9 is the only well with a concentration exceeding the WHO norms (Figure 27) and this, in the month of June. 


\section{Legend}

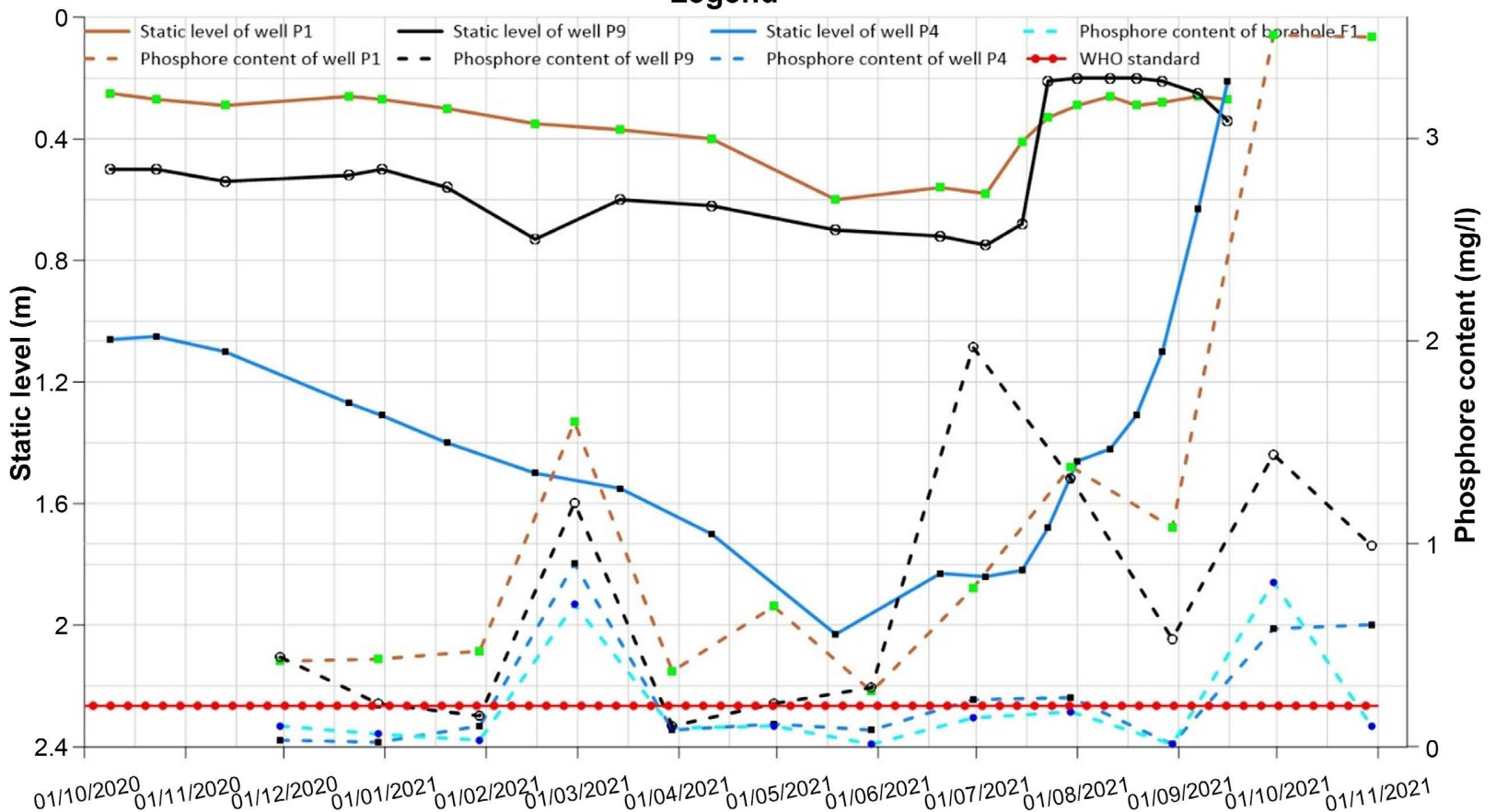

Date

Figure 26. Variation in phosphorus as a function of piezometry.

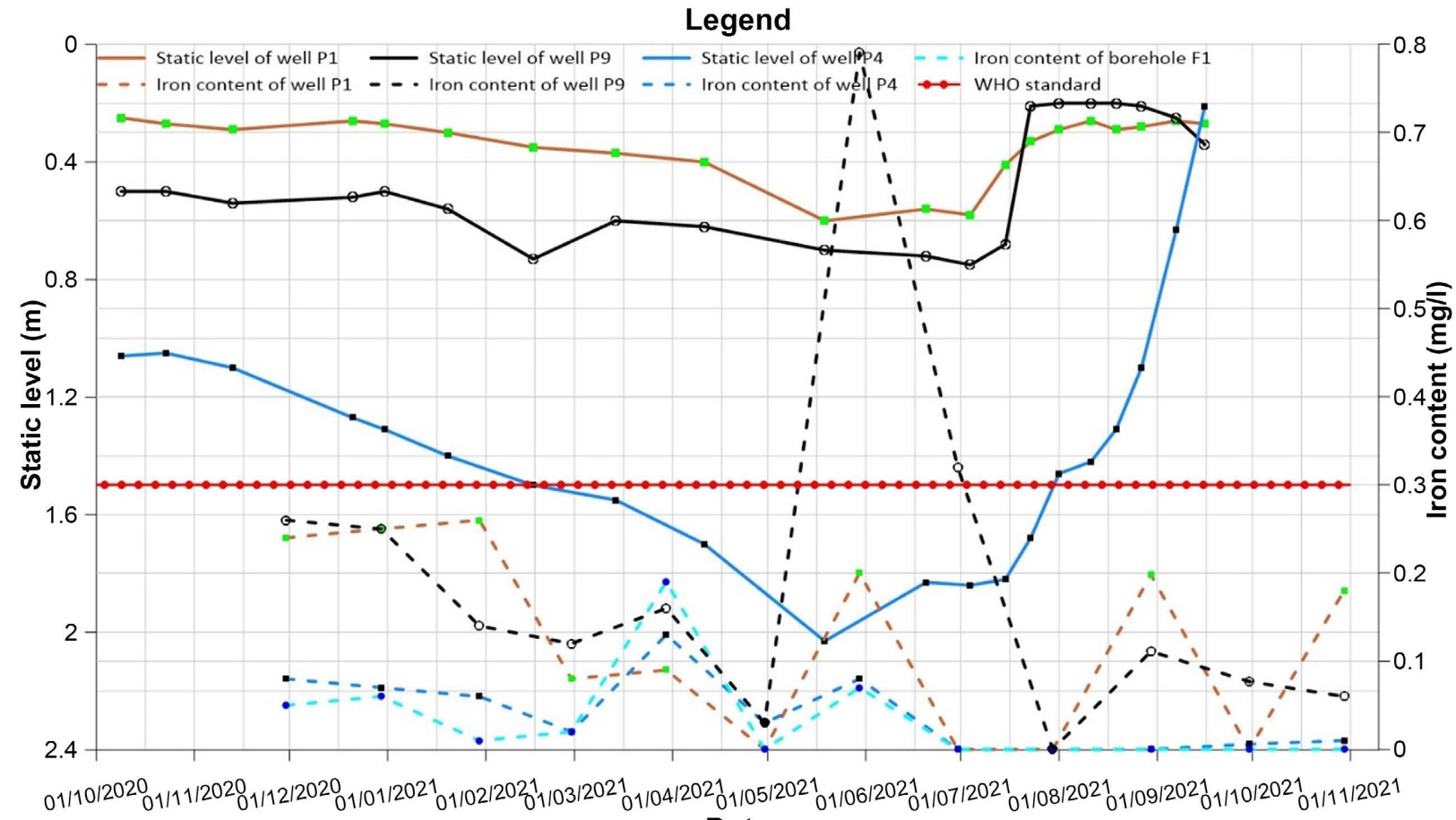

Date

Figure 27. Variation of iron as a function of piezometry.

Table 2 summarizes all the elements of the water points whose concentrations exceeded the WHO standards according to the month of measurement. A total of 05 elements out of the 17 measured exceeded WHO standards. 
Table 2. Summary table of elements exceeding WHO standards.

\begin{tabular}{ccl}
\hline Sampling points & Element & \multicolumn{1}{c}{ Analysis date } \\
\hline Well P4 & Nitrate & March \\
Well P1 & Nitrate & March \\
Well P1 & Potassium & August and September \\
Well P9 & Potassium & All the year except May and July \\
Well P1 & Ammonium & April, June, August, September and October \\
Well P9 & Ammonium & March, June, July, August, September and October \\
Well P4 & Ammonium & June, October and November \\
Well P1 & Phosphorus & All the year \\
Well P9 & Phosphorus & All the year except February and April \\
Well P4 & Phosphorus & March, July, August and October \\
Borehole F1 & Phosphorus & March and October \\
Well P9 & Iron & June \\
\hline
\end{tabular}

\subsection{Microbiological Parameters (E-Colis)}

The bacterial load is slightly elevated in the hot dry season for P9 sub-surface (Figure 28); this load decreases during all the other two periods of the year for this sampling point. It is much higher in the wet season for wells P1 and P3 than in the hot dry season and finally in the cold season (Figure 28). It remains constant throughout the year at well F1.

All sampling points except well F1 are contaminated by agents of fecal origin. The quantity of microorganisms present in the water increases with rainfall, apparently for groundwater, although no study to date has been able to establish a simple law formally modeling these two parameters. Microorganisms are very common in surface water, but increasingly also in groundwater (Figure 28). This contamination occurs especially when the groundwater is fed by rainwater infiltration or directly by polluted water. They are the group of pollutants that cause the most diseases. It should be noted that the survival time of pathogens (bacteria) is shorter in acid soils ( $\mathrm{pH} 3$ - 5) than in basic soils.

The comparison of results before and after chlorination and emptying of the wells shows no difference, which indicates that the contamination measured is that of the water table, and not that induced locally by operating conditions and by land use in the immediate vicinity of the wells.

\subsection{Origin and Factors of Pollution of Water for Domestic Use}

The origin of water pollution can be natural or anthropogenic [42]. The main factors that control the physical-chemical and bacteriological quality of water are anthropogenic activities, hydrogeological context and climate [43]. [42] clarifies that the main sources of anthropogenic pollution are agriculture, which is applied diffusely over the territory; industries, which are the source of very diverse 


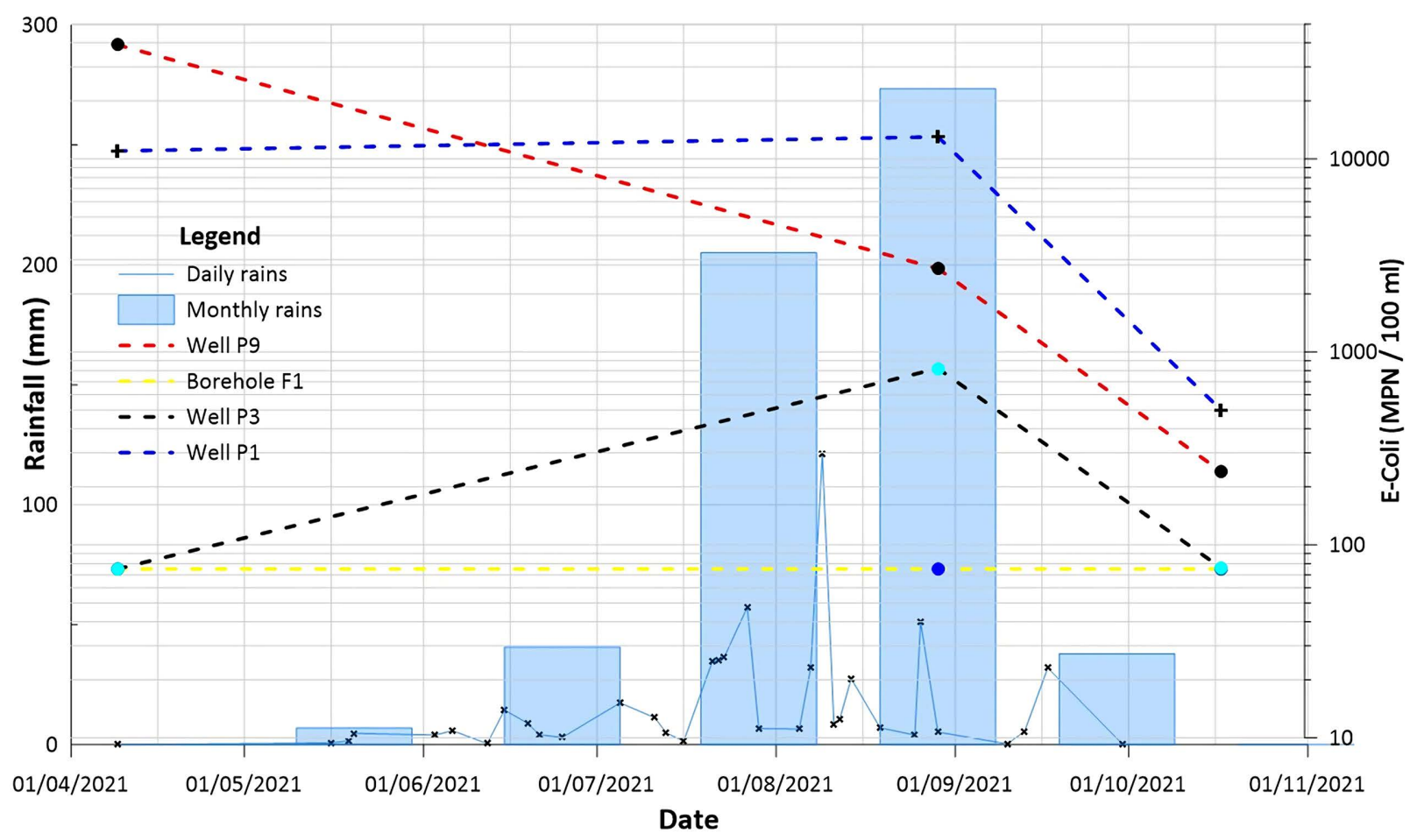

Figure 28. Variation in e-Coli populations in the ground water according to the rainfall.

and often localized discharges; and domestic activities via wastewater discharges or landfills. [17] distinguished four sources of pollution in the city of Niamey, including domestic sources, industrial sources, hospital sources and agricultural sources.

Several authors have identified factors such as activities around wells, lack of good development, proximity to sources of pollution such as urban waste, uncontrolled garbage dumps, individual sanitation facilities (latrines, cesspools, septic tanks), and failure of users to observe basic hygiene rules as the cause of pollution (microbial and/or chemical) of well water in urban areas. Some authors have estimated an increase in the rate of contamination during the rainy season compared to the dry season [6]. Seepage water favors pollution from septic tanks and leaky latrines [44] that are interconnected with wells, as in the case of Gounti Yéna valley basin.

The presence of nitrites and nitrates in the water, therefore, comes from deficient septic installations; fertilizers, wastewater, landfills, runoff, leaching of land by precipitation and oxidation of nitrogen, oxidation of nitrites by bacteria following the infiltration of wastewater.

\section{Conclusions}

The path followed by water from the soil surface to the aquifer system gives it its characteristic chemical quality. It acquires several forms before reaching its final location (the water table) where it stays with more or less long contact with the reservoir rock for the acquisition of its mineralization. The surface water is gen- 
erally shallow and outcropping in the context of this study with a maximum level of less than $3 \mathrm{~m}$, which means that they create permanent pools in some places that are much more exposed to pollution, especially in urban areas like Niamey. The communication between surface water and subsurface water leads to the transfer of certain water quality parameters.

This study of monthly follow-up over a period of one year is carried out with the aim of characterizing, for the first time, the quality of the water of Gounti Yéna basin in front of the new phenomenon of flooding due to the water table. This work provides important information based on physico-chemical and bacteriological descriptors.

The wastewater discharges and the septic tank-groundwater interconnection in this area are therefore largely responsible for any bacterial and chemical pollution of the groundwater. The communication between the SEEN drinking water distribution network and the contaminated water bodies makes the distributed water potentially polluted, constituting a source of waterborne diseases.

Groundwater has a relatively constant content of various elements, but this can change rapidly with the arrival of the first rains. The results obtained show that the spatio-temporal variation of the bacterial load of the water of Gounti Yéna is much higher in the hot dry season, relatively high in the rainy season and lower in the cold dry season.

\section{Acknowledgements}

The authors would like to thank Manuella GRIPPA and Moussa BOUBACAR (Geosciences Environnement Toulouse-France) for providing equipment and technical assistance in the context of microbiological monitoring. The authors also thank the project: "Health risks and resilience to climate and environmental change" (RISARCHES) for providing them with reagents to monitor the various parameters.

\section{Conflicts of Interest}

The authors declare no conflicts of interest regarding the publication of this paper.

\section{References}

[1] Ghazali and Zaid (2013) Study of the Physico-Chemical and Bacteriological Quality of the Water of the Ain Salama-Jerri Spring (Meknes Region-Morocco).

[2] Alassane Hado, H., Adamou, M.M., Favreau, G., Boucher, M., Hima, K. and Dan Dano, I. (2021) Rise of Urban Water Table as a Cause of Flooding: Improving Knowledge in the City of Niamey (Niger Republic). Journal of Water Resource and Protection, 13, 976-999. https://doi.org/10.4236/jwarp.2021.1312053

[3] Favreau, G. (2000) Characterization and Modeling of a Rising Water Table in the Sahel: Dynamics and Geochemistry of the Natural Piezometric Depression of the Dantiandou Kori (Southwestern Niger). Thesis of the University of Paris XI, Paris, 258 p. + Annexes. 
[4] Mahé, G.I.L., Leduc, C., Amani, A., Paturel, J.E., Girard, S.A., Servat, E. and Dezetter, A. (2003) Recent Increase in Surface Runoff in the Sudano-Sahelian Region and Impact on Water Resources. IAHS Publication, 215-222.

[5] Favreau, G., Cappelaere, B., Massuel, S., Leblanc, M., Boucher, M., Boulain, N. and Leduc, C. (2009) Land Clearing, Climate Variability, and Water Resources Increase in Semiarid Southwest Niger: A Review. Water Resources Research, 45, W00A16. https://doi.org/10.1029/2007WR006785

[6] Boubakar, H.A. (2010) Surface and Deep Aquifers and Urban Pollution in Africa: Case of the Urban Community of Niamey (NIGER). Thesis of the Univ. Abdou Moumouni, Niamey, $250 \mathrm{p}$.

[7] Oumarou, H. (2017) LASDEL, Abdourahamane Oumarou: Humanitarian Flood Management in a Commune of Niamey. Report.

[8] Julvez, J., Badé, M.A., Lamotte, M., Campagne, G., Garba, A., Gragnic, G., Bui, A., Kehren, S., Cluzel, F. and Chippaux, J.-P. (1998) Intestinal Parasitosis in the Urban Environment of the Sahel. Study in a Neighborhood of Niamey, Niger.

[9] Joseph, A. and Ousmane, B. (1988) Nitrate Pollution of the Alluvial Groundwater of the Niger River in Niamey. Annahda International University, 3, 129.

[10] Joseph, A. and Girard, P. (1990) Study of Nitrate Pollution of Basement Aquifers: Example of the Niamey Aquifer. Ministry of Hydraulics of Niger.

[11] ABN-BGR (2018) Physicochemical and Piezometric Characterization of Aquifers in the Niamey Area. Report n ${ }^{\circ} 6.120$ p.

[12] Bui, A. (1996) Bacteriological and Physico-Chemical Quality of Well and Borehole Water in Niamey (Niger). Dissertation of Professional Degree, Claude-Bernard University, Paris.

[13] United Nations Development Programme (UNDP) (2006) Human Development Report.

[14] Sy, B., Frischknecht, C., Dao, H., Giuliani, G., Consuegra, D., Wade, S. and Kêdowidé, C. (2016) Participatory Approach for Flood Risk Assessment: The Case of Yeumbeul Nord (YN), Dakar, Senegal. WIT Transactions on the Built Environment, 165, 331-342. https://doi.org/10.2495/UW160291

[15] Motcho, H.K. (2004) Urban Growth and Insecurity in the City of Niamey.

[16] Henri, M.K. and Hadiara, Y.S. (2020) Gounti Yéna, an Ignored Heritage of Niamey in Danger of Disappearing. Article Abdou Moumouni University of Niamey, Niamey, 259-264.

[17] Bassirou, A. (2007) Impact of Discharges from the City of Niamey (Niger) on the Water Quality of the Niger River. Doctoral Thesis, The University Notre-Dame de LA Paix Namur, Namur, 299 p.

[18] Alhou, B., Darchambeau, F., Bouillon, S. and Borges, A. (2013) Sources, Transport and Transformation of Carbon, Nitrogen and Phosphorus in the Niger River: Results after 2 Years of Observations in Niamey.

[19] Gado, F.A. (2018) Study of Soils Polluted by Metallic Trace Elements in Gounti Yéna Valley in Niamey (Niger) for the Implementation of a Phytoremediation Process. Thesis of the Abdou Moumouni University, Niamey, $290 \mathrm{p}$.

[20] (2018) Update of the Master Plan for Liquid Sanitation and Stormwater Drainage of the City of Niamey-Niger. Mission a Report.

[21] Gaüzère, B.-A. and Aubry, P. (2012) Cholera Epidemics in Réunion in the 19th Century. Tropical Medicine and Health, 22, 131-136.

https://doi.org/10.1684/mst.2012.0044 
[22] Bechler-Carmaux, N. and Mletton, M. (1999) The Risk of Drinking Water Shortage in the City of Niamey (Niger).

[23] Coulibaly, K. (2005) Study of the Physico-Chemical and Bacteriological Quality of Water from Wells in Certain Neighborhoods in the District of Bamako.

[24] Pigeon, J.-L. (2000) Impact Study of the Water Sector Project (Republic of Niger). Final Report, 145 p.

[25] Leduc, C. and Loireau, M. (1997) Piezometric Fluctuations and Evolution of the Vegetation Cover in the Sahelian Zone (Southwestern Niger).

[26] Guergazi, S. and Achour, S. (2005) Physico-Chemical Characteristics of the Water Supply of the City of Biskra. Practice of Chlorination. Larhyss Journal, 4, 119-127.

[27] Greigert, J. (1966) Groundwater in the Republic of Niger. Ministry of Public Works, Transport, Mines and Urbanism of the Republic of Niger. BRGM Report. 407 p.

[28] Leduc, C., Taupin. J.D. and Le Gal La Salle, C. (1996) Estimation of Groundwater Recharge at the Continental Terminal (Niamey, Niger) Based on Tritium Levels. Comptes Rendus de 1 Académie des Sciences, 323, 599-605.

[29] Durand, J.R. and Lévêque, C. (1980) Aquatic Flora and Fauna of Sahelo-Sudanian Africa: Volume 1.

[30] APHA-AWWA-WPCF (1981) Standard Methods for the Examination of Water and Wastewater. 15th Edition, American Public Health Association, Washington DC.

[31] Gomaah, M., Ramadan, A., El-Shazly, M., Abdulhady, Y. and Shawky, H. (2021) Physicochemical and Bacteriological Quality of Groundwater, East of Nile Delta of Egypt. Journal of Geoscience and Environment Protection, 9, 97-106. https://doi.org/10.4236/gep.2021.91008

[32] Burnol, A., Duro, L. and Grive, M. (2006) Trace Metals: Methodological Guide. Study Report.

[33] Payment, P. and Hartemann, P. (1998) Water Contaminants and Their Effects on Health. Journal of Water Science, 11, 199-210. https://doi.org/10.7202/705338ar

[34] Hem, J.D. (1985) Study and Interpretation of the Chemical Characteristics of Natural Water. Water Supply Paper 2254, 3rd Edition, United States Geological Survey, Reston.

[35] Leduc, C. and Taupin, J.D. (1993) Hydrochemistry on the Continental Terminal Phreatic Aquifer near Niamey (Niger).

[36] El Ghachtoul, Y., Alaoui Mhamidi, M. and Gabi, H. (2005) Eutrophication of the Water of the Smir and Sehla Dams (Morocco): Causes, Consequences and Management Guidelines. Journal of Water Science, 18, 75-89. https://doi.org/10.7202/705577ar

[37] Liechti, P. (2010) Methods of Analysis and Assessment of Watercourses. PhysicoChemical Analyses, Nutrients. The Practical Environment n 1005. Federal Office for the Environment, Bern, $44 \mathrm{p}$.

[38] Monfort, M. (1997) Study of the Relations between the Aquifers of the Continental Terminal North of Niamey (Niger): Geological, Geochemical and Hydrodynamic Approach. DEA, University of Paris-Sud, Paris, 152 p.

[39] Kehren, S. (1995) The Agglomeration of Niamey (Niger) Contribution to a Better Knowledge of Water Availability and Needs. Master's Thesis in Geography, Université L. Pasteur UFR de Géographie, Center for Eco-geographic Studies and Research (CEREG-URA 95-CNRS).

[40] Leduc, C. and Taupin, J.-D. (1997) Hydrochemistry and Recharge of the Continental Terminal Water Table (Niamey, Niger). 
[41] Gross, P. (1998) Groundwater Quality of the Urban Community of Niamey. Progress Report of the Work. Document CERMES 22/98.

[42] Leduc, C. and Lenoir, F. (1995) Study of the Recharging of the Continental Terminal 3 napp in the Left River of Niger.

[43] Ouhmidou, M. and Chahlaoui, A. (2013) Physico-Chemical Quality of the Water of the Hassan Addakhil Dam of Errachidia-Morocco. Science Lib Editions Mersenne, Volume 5, $\mathrm{N}^{\circ} 130908$.

[44] Kenfaoui, A. (2008) Let's Save Water by Preserving It from Pollution. REV HTE, 140, 140-17. 